\title{
Neuropeptide Y receptors: how to get subtype selectivity
}

\section{Xavier Pedragosa-Badia, Jan Stichel and Annette G. Beck-Sickinger*}

Institute of Biochemistry, Faculty of Biosciences, Pharmacy and Psychology, Universität Leipzig, Leipzig, Germany

\section{Edited by:}

Hubert Vaudry, University of Rouen,

France

\section{Reviewed by:}

Janine A. Danks, Royal Melbourne Institute of Technology-University, Australia

William Colmers, University of

Alberta, Canada

\section{*Correspondence:}

Annette G. Beck-Sickinger, Institute of Biochemistry, Faculty of Biosciences,

Pharmacy and Psychology, Universität Leipzig, Brüderstraße 34, 04103

Leipzig, Germany.

e-mail: beck-sickinger@uni-leipzig.de
The neuropeptide $Y$ (NPY) system is a multireceptor/multiligand system consisting of four receptors in humans $\left(\mathrm{hY} \mathrm{Y}_{1}, \mathrm{hY_{2 }}, \mathrm{hY_{4 }}, \mathrm{hY_{5 }}\right.$ ) and three agonists (NPY, PYY, PP) that activate these receptors with different potency. The relevance of this system in diseases like obesity or cancer, and the different role that each receptor plays influencing different biological processes makes this system suitable for the design of subtype selectivity studies. In this review we focus on the latest findings within the NPY system, we summarize recent mutagenesis studies, structure activity relationship studies, receptor chimera, and selective ligands focusing also on the binding mode of the native agonists.

\section{Keywords: GPCR, NPY, YR, subtype selectivity, ligand side, receptor side}

\section{INTRODUCTION TO THE NEUROPEPTIDE Y FAMILY}

The neuropeptide Y (NPY) family is a multireceptor/multiligand system consisting of four receptors in humans and three polypeptides that bind and activate them with different affinity and potency. The NPY receptors belong to the class A or rhodopsinlike G-protein coupled receptors (GPCR). Five receptors have been cloned from mammals so far, $\mathrm{Y}_{1}, \mathrm{Y}_{2}, \mathrm{Y}_{4}, \mathrm{Y}_{5}$, and $\mathrm{y}_{6}$ but only four of the members are functional in humans $\left(\mathrm{hY}_{1}, \mathrm{hY}_{2}\right.$, $\mathrm{hY}_{4}, \mathrm{hY}_{5}$; Table 1). The y6 receptor however is active in rabbit and mouse (Starback et al., 2000). The existence of an additional receptor subtype $\left(\mathrm{Y}_{3}\right)$ was suggested by pharmacological studies of several human, rat, and rabbit tissues including the human adrenal medulla. This receptor subtype is characterized by a much lower affinity for PYY, compared to NPY (Gehlert, 1998; Lee and Miller, 1998). However, since all attempts to clone this receptor subtype were unsuccessful so far, the existence of $Y_{3}$ is not very likely.

Neuropeptide Y receptors (NPYR) generally couple to $G_{i}$ or $\mathrm{G}_{0}$ proteins, which leads to the inhibition of adenylate cyclase and finally to the inhibition of cAMP accumulation (Cabrele and BeckSickinger, 2000) and modulation of $\mathrm{Ca}^{2+}$ and $\mathrm{K}^{+}$channels (Holliday et al., 2004). Besides this, it has been described that $Y_{2}$ and $Y_{4}$ receptors also couple to the $\mathrm{G}_{\mathrm{q}}$ protein increasing inositol 1,4,5phosphate $\left(\mathrm{IP}_{3}\right)$ production via the activation of the phospholipase C- $\beta$ (PLC) in rabbit smooth muscle cells (Misra et al., 2004).

Neuropeptide Y, peptide YY (PYY), and pancreatic polypeptide (PP) are the native ligands of the NPY family. NPY is the most abundant peptide in the mammalian brain and has been suggested to adopt a largely open structure. In surface association with phospholipid micelles a flexible $\mathrm{N}$-terminus and a C-terminal alpha helix were identified (Lerch et al., 2004; Parker et al., 2011). However, PYY and PP are suggested to form the typical hairpinlike structure also called PP-fold, a suggestion for PPYY supported by NMR (Keire et al., 2000a; Neumoin et al., 2007), and for PP by the X-ray structure of the peptide (Blundell et al., 1981). Despite some structural differences between the ligands, these polypeptides have a common length of 36 amino acids (Table 2) and an amidated C-terminus. Furthermore, these polypeptides share high sequence identity. Whereas NPY and PYY show the highest percentage of common residues with 70\%, NPY and PP share only 50\% identity (Blomqvist et al., 1992; Zhang et al., 2011). Seven positions in NPY, PYY, and PP are strongly conserved throughout all species: $\mathrm{Pro}^{5}, \mathrm{Pro}^{8}, \mathrm{Gly}^{9}, \mathrm{Ala}^{12}, \mathrm{Tyr}^{27}, \mathrm{Arg}^{33}$, and $\mathrm{Arg}^{35}$. Apart from these, highly conserved positions are: $\mathrm{Pro}^{2}, \mathrm{Tyr}^{20}, \mathrm{Thr}^{32}$, and $\mathrm{Tyr}^{36}$ (Cabrele and Beck-Sickinger, 2000). Regarding its pharmacological properties, NPY acts as a neurotransmitter whereas PYY and PP act as neuroendocrine hormones.

The first identified member of the family PP, was isolated from avian pancreas in 1975 (Kimmel et al., 1975). This polypeptide is secreted in the pancreas by PP cells in the Langerhans islets after food ingestion in proportion to the caloric content (Boguszewski et al., 2010; Suzuki et al., 2010). It is thought to act mainly in brain stem and vagal nerve where it promotes appetite suppression, inhibition of gastric emptying and increases in energy expenditure (Asakawa et al., 2003) in addition to direct responses in the gut.

The second member of the ligand family PYY, was isolated from porcine intestinal extracts in 1980 (Tatemoto and Mutt, 1980) and is expressed by entero-endocrine L cells of the distal gut (Lundberg et al., 1982). $\mathrm{PYY}_{1-36}$ is released in proportion to nutrient intake along the gut and cleaved to $\mathrm{PYY}_{3-36}$ by the dipeptidyl aminopeptidase VI. The ligand $\mathrm{PYY}_{3-36}$, the predominant form released in the circulation, is selective for $\mathrm{Y}_{2}$ and produces anorexigenic effects (Pittner et al., 2004). This polypeptide acts on peripheral receptors but also on those located in the CNS (Hankir et al., 2011; Schloegl et al., 2011). The last family member, NPY, was isolated from porcine brain in 1982 (Tatemoto, 1982) and is one of the most broadly distributed peptides of the central and peripheral nervous system. This peptide is well conserved among different species. It stimulates food intake in response to negative energy balance (Stanley et al., 1986). Additional roles of NPY are decreased bone 
Table 1 | Amino acid sequence of the NPY ligands.

\begin{tabular}{|c|c|c|c|c|c|c|c|c|c|c|c|c|c|c|c|c|c|c|c|c|c|c|c|c|c|c|c|c|c|c|c|c|c|c|c|c|}
\hline \multirow[t]{2}{*}{ Peptides } & \multicolumn{36}{|c|}{ Amino acid sequence } \\
\hline & 1 & & & & 5 & & & & & 10 & & & & & 15 & & & & & 20 & & & & & 25 & & & & & 30 & & & & & 35 & \\
\hline pNPY & $Y$ & P & $S$ & $K$ & $P$ & $D$ & $N$ & $P$ & G & $E$ & $D$ & $A$ & $P$ & A & $E$ & $D$ & $\mathrm{~L}$ & A & $\mathrm{R}$ & $Y$ & Y & $S$ & $A$ & $L$ & $\mathrm{R}$ & $\mathrm{H}$ & $Y$ & I & $N$ & $L$ & 1 & $\mathrm{~T}$ & $\mathrm{R}$ & O & $\mathrm{R}$ & $Y$ \\
\hline hPYY & Y & $\mathrm{P}$ & I & $\mathrm{K}$ & $P$ & $E$ & A & $\mathrm{P}$ & G & $E$ & D & $A$ & S & $P$ & $E$ & $E$ & $\mathrm{~L}$ & $\mathrm{~N}$ & $\mathrm{R}$ & Y & Y & $A$ & S & $\mathrm{L}$ & $\mathrm{R}$ & $\mathrm{H}$ & Y & $L$ & $\mathrm{~N}$ & $L$ & V & $\mathrm{T}$ & $\mathrm{R}$ & $\mathrm{O}$ & $\mathrm{R}$ & Y \\
\hline hPP & A & $\mathrm{P}$ & $\mathrm{L}$ & $E$ & $P$ & V & Y & $P$ & $G$ & $D$ & $N$ & $A$ & $\mathrm{~T}$ & $P$ & $E$ & $\mathrm{O}$ & $\mathrm{M}$ & $A$ & $\mathrm{O}$ & $Y$ & $A$ & $A$ & $\mathrm{D}$ & $\mathrm{L}$ & $\mathrm{R}$ & $\mathrm{R}$ & $Y$ & 1 & $\mathrm{~N}$ & $\mathrm{M}$ & $\mathrm{L}$ & $\mathrm{T}$ & $\mathrm{R}$ & $P$ & $\mathrm{R}$ & $Y$ \\
\hline
\end{tabular}

Table 2 | NPYR: sequence length and ligand preference.

\begin{tabular}{lllll}
\hline Receptor & $\mathbf{h \mathbf { 1 } _ { \mathbf { 1 } }}$ & $\mathbf{h \mathbf { Y } _ { \mathbf { 2 } }}$ & $\mathbf{h \mathbf { Y } _ { \mathbf { 4 } }}$ & $\mathbf{h \mathbf { Y } _ { \mathbf { 5 } }}$ \\
\hline Amino acids number & 384 & 381 & 375 & $445-455$ \\
Native ligand & NPY & NPY & PP & NPY \\
& PYY & PYY & & PYY \\
\hline
\end{tabular}

formation (Baldock et al., 2009; Sousa et al., 2012), regulation of mood and anxiety disorders, the modulation of stress responses (Heilig, 2004), and ethanol intake (Thiele et al., 1998).

Neuropeptide Y family peptides mediate their activity in humans via four receptors. Structurally, these receptors contain two Cys residues in the extracellular regions that form a disulfide bond between extracellular loop I and II. This disulfide bond is a common feature of class A GPCRs and has been confirmed by X-ray crystallography for several members including bovine rhodopsin and the human $\beta 2$ adrenergic receptor (Palczewski et al., 2000; Cherezov et al., 2007).

The evolution of this system shows that vertebrate ancestors probably had three receptor genes. These genes, possibly located in close proximity in the same chromosomal segment, would be the precursors of the receptor subfamilies. The $\mathrm{Y}_{1}$ subfamily includes the $\mathrm{Y}_{1}, \mathrm{Y}_{4}$, and $\mathrm{y}_{6}$ receptors, the $\mathrm{Y}_{2}$ subfamily comprises $\mathrm{Y}_{2}$ and $\mathrm{Y}_{7}$ (in zebrafish and frogs), and the $\mathrm{Y}_{5}$ subfamily consists of only the $\mathrm{Y}_{5}$ due to lack of close relatives of this receptor (Larhammar and Salaneck, 2004). Although the $\mathrm{Y}_{1}$ and $\mathrm{Y}_{2}$ receptor subtypes have a common pharmacological profile, they only share $27 \%$ of sequence identity. $\mathrm{Y}_{1}$ and $\mathrm{y}_{6}$ receptors share the highest sequence identity (51\%), whereas $\mathrm{Y}_{1}$ and $\mathrm{Y}_{4}$ receptors share $44 \%$ identity, increasing to $56 \%$ identity in transmembrane regions (Larhammar et al., 2001). The $\mathrm{Y}_{4}$ receptor conserves $75 \%$ of overall identity between human and rat suggesting this protein may be the most rapidly evolving member of the family and the only member that has a selective agonist, the pancreatic polypeptide (Larhammar, 1996; Blomqvist and Herzog, 1997). The Y 5 receptor displays low sequence identity, around 30\%, with all members of the family. Compared with other GPCRs, neuropeptide Y receptors share a high sequence identity with $\mathrm{NPFF}_{1}$ and $\mathrm{NPFF}_{2}$ receptors, which are members of the RFamide receptor family (Bonini et al., 2000).

The $\mathrm{Y}_{1}$ receptor has 384 amino acids and its main agonists are NPY and PYY. It can be also activated by PP with a minor potency (Table 2). The receptor is expressed in the hypothalamus, hippocampus, neocortex, and thalamus (Caberlotto et al.,
1997), but is also present in adipose tissue (Castan et al., 1993; Hausman et al., 2008), blood vessels (Cabrele and Beck-Sickinger, 2000), colon, kidney, adrenal gland, heart, and placenta (Wharton et al., 1993). It plays a role in the regulation of food intake (Kanatani et al., 2000b), vasoconstriction of blood vessels (Cabrele and Beck-Sickinger, 2000), heart rate, anxiety (Balasubramaniam, 2002), and bone homeostasis (Sousa et al., 2012).

The $\mathrm{Y}_{2}$ receptor is predominantly expressed in hippocampal neurons, in the thalamus, hypothalamus, and parts of the peripheral nervous system (Widdowson, 1993; Cabrele and BeckSickinger, 2000). It is mainly found in pre-synaptic neurons and exerts its action through the regulation of neurotransmitter release (Wahlestedt et al., 1986; Potter et al., 1989). Typical effects correlated with activation of this receptor include enhanced memory retention, the regulation of the circadian rhythm, angiogenesis (Flood and Morley, 1989; Golombek et al., 1996; Gribkoff et al., 1998; Zukowska-Grojec et al., 1998) and bone formation (Baldock et al., 2002). This receptor consists of 381 amino acids and its preferred agonists are NPY and PYY (Table 2).

The $\mathrm{Y}_{4}$ receptor subtype is the only member of the family with the endogenous agonist PP, while PYY and NPY can still activate this receptor with minor potency (Table 2). It consists of 375 amino acids and is mainly expressed in the gastrointestinal tract (Lundell et al., 1995; Ferrier et al., 2002) but also in the brain (Bard et al., 1995), as well as pancreas and prostate (Lundell et al., 1995). It plays a role in the regulation of feeding (Asakawa et al., 1999; Sainsbury et al., 2010), circadian ingestion and energy homeostasis (Edelsbrunner et al., 2009), colonic transit (Moriya et al., 2010), and stimulation of the luteinizing hormone release (Jain et al., 1999).

The $\mathrm{Y}_{5}$ receptor subtype is expressed in two different splice variants, composed of 445 and 455 amino acids, respectively (Table 1). The N-terminus of the longer isoform is extended by 10 amino acids. However, these differences in the sequence of the receptor isoforms do not result in differences in their pharmacological profile (Rodriguez et al., 2003). Both receptor isoforms bind NPY and PYY with comparable affinities. The affinity for PP is slightly lower, but still in the nanomolar range (Gerald et al., 1996). $Y_{5}$ receptors are mainly expressed in the central nervous system. Tissues with high receptor density include the hippocampus and hypothalamus. The $\mathrm{Y}_{5}$ receptor subtype has been shown to be strongly involved in food intake (Gerald et al., 1996). Other possible roles of the $\mathrm{Y}_{5}$ receptor are the regulation of the circadian rhythm (Matsumoto et al., 1996b; Gribkoff et al., 1998) and reproduction through inhibition of LH release (Raposinho et al., 2001). 
The y6 receptor encodes a 371 amino acid protein that has been cloned from rabbit, mouse, and chicken among others (Bromee et al., 2006). However, the sequence in humans and monkeys contains a frame shift mutation in the third intracellular loop, resulting in a non-functional truncated receptor protein (Matsumoto et al., 1996a; Michel et al., 1998).

Taken together, this multireceptor/multiligand system mediates many relevant physiological and pathological processes. This makes the NPY family truly attractive for the design of subtype selective analogs and receptors. Even if selective ligands are pharmacologically the most attractive approach to tackle subtype selectivity, development of receptor chimeras or receptor mutants will also help to understand how the receptors refined their binding pockets during evolution and, as a result, will show how the ligands tend to have distinct affinities for one or the other receptor subtype.

\section{DEVELOPING SELECTIVE LIGANDS FOR NPY RECEPTORS}

As it has been previously described, the binding affinity of each peptide differs from receptor to receptor and the role that each receptor plays in regulating physiological processes is different. In light of this, the NPY system is a perfect candidate in which to develop selective ligands and selective receptors to modulate these characteristics.

\section{GENERAL STRATEGIES}

The most conventional way of investigating subtype selectivity is the synthesis of selective ligands. Consequently, to obtain subtype selective ligands, the peptides have to be modified in key positions allowing the investigator to modulate the ligand preference for a receptor. Although the peptides of the NPY family share high sequence homology, they do not necessarily have the same binding mode. The truncation of certain fragments can direct the selectivity to a certain receptor subtype providing information about essential fragments of the peptide. Therefore, one of the approaches to investigate important positions on the peptides are $\mathrm{N}$ - or C- terminal truncations.

Another approach to investigate subtype selectivity is the alanine-scan or Ala-scan: this means that each residue in the sequence is one by one individually substituted with Ala. When an Ala occurs naturally in a certain position, this residue is then changed to Gly. In this scan, only the functional groups are substituted permitting the investigation of ionic interactions as well as dipole-dipole and hydrophobic interactions. Once all the analogs are synthesized they must be tested at all the receptor subtypes to determine how the substitution of the native amino acid affects the binding or the activation. In case a residue shows a great loss in binding or activation for a certain receptor, further exchanges in this position can be done. For example the exchange of a certain residue of NPY by the residue present in PP can achieve $\mathrm{Y}_{4}$ receptor binding with the analog. The use of $\mathrm{D}$-amino acids in a scan can provide information about the side chain orientation and steric information concerning ligand binding too, Pro-scans reveal favorable turn-structures and Phe-scans hydrophobic interactions (Lindner et al., 2008a).

As small peptides can adopt several active conformations and these conformations can be recognized by different receptor subtypes in structure-activity relationships, the knowledge of these binding subtypes is of great interest. Furthermore, to investigate the binding mode and receptor preference of small antagonists or non-peptidic drugs, knowledge of the bioactive conformation is of major importance. Constraining the ligand conformation and testing the peptide on several receptor subtypes, can provide information about its bioactive conformation and receptor selectivity. Several strategies can be used to investigate structure activity relationships constraining the conformation of small peptides (Beck-Sickinger, 1997). First of all, non-proteinogenic amino acids can be incorporated, reducing the number of angle combinations that a natural amino acid could adopt, and thereby decreasing the flexibility of the peptide. One example of a non-proteinogenic amino acid is Aib (aminoisobutyric acid). This residue is one the most commonly used in this kind of study. Secondly, the use of several templates and amino acid linkers to induce a desired conformation might be also a good strategy, although this does not always lead to the desired effect because of other amino acids within the sequence. The use of more flexible linkers such as Ahx (6-aminohexanoic acid) or $\omega$-amino alkanoic acids might be a better method to determine the distance between two segments. Finally, the use of cyclization can significantly constrain the conformation of a ligand. Several cyclization techniques can be applied, the most commonly used are: cyclization by disulfide formation between two Cys residues, cyclization by lactamization of $\mathrm{N}$ - and/or C-terminus or by the $\mathrm{N}$ - and C-group-containing side chains Lys, Orn, Dab, Asp, and Glu and backbone to sidechain cyclization. Recent studies also use click reactions to cyclize peptides using triazoles to mimic disulfide bridges (Holland-Nell and Meldal, 2011) and peptide stapling to increase the propensity to form $\alpha$-helices, therefore improving pharmacological properties (Verdine and Walensky, 2007).

\section{$\mathrm{Y}_{\mathbf{1}}$ RECEPTOR}

$\mathrm{N}$-/C-terminal truncations of NPY confirm the importance of these two segments for $\mathrm{Y}_{1}$ receptor binding. N-terminally truncated analogs are not well accepted by the $Y_{1}$ receptor as can be seen in studies using the shortened sequences NPY(3-36), (13-36), and (18-36). These show only micromolar affinities for this receptor and even the truncation of the first amino acid NPY(2-36), results in a loss of affinity (Beck-Sickinger and Jung, 1995). C-terminal truncations show the importance of the amide group in the binding with the receptor (Hoffmann et al., 1996). Centrally truncated analogs containing the spacer Ahx and structurally constrained analogs showed that the $\mathrm{N}$ - and C-terminal fragments must have a certain length to bind with a good affinity to the receptor (Kirby et al., 1993b). Furthermore, using an Ala-scan it was found that, $\mathrm{Pro}^{2}, \mathrm{Pro}^{5}, \mathrm{Arg}^{19}$, and $\mathrm{Tyr}^{20}$ are important for ligand affinity. Also the amino acids from positions 27 to 36 were found to be crucial for the peptide, especially position 27. Moreover, positions 33 and 35 showed to be extremely important, as Ala analogs at these positions produced a dramatic loss in binding of $>5000$-fold over wt (Figure 3; Beck-Sickinger et al., 1994; Cabrele and Beck-Sickinger, 2000; Lindner et al., 2008b). The importance of $\operatorname{Arg}^{35}$ was further confirmed as this residue was found to form a subtype-specific ionic interaction with $\mathrm{Asp}^{6.59}$ of the receptor (Merten et al., 2007). The Tyr on position 36 was also found to be relevant for the ligand 
binding; this position does however tolerate the exchange to Phe, but not Ala, Bpa, or His. Similar results were obtained using a D-amino acid scan (Kirby et al., 1993a).

Positions 7, 25, 26, 31, and 34 were revealed to be important for subtype selectivity (Figure 1A). Modifications in positions 25 and 26 showed that [D-Arg ${ }^{25}$ ]NPY and [D-His ${ }^{26}$ ]NPY bind selectively to the $\mathrm{Y}_{1}$ receptor (Mullins et al., 2001). Also the introduction of Pro in position 34, present in pancreatic polypeptide, redirected the affinity of the peptide to $Y_{1} / Y_{5}$ receptors. Apart from $\mathrm{Gln}^{34}$, an additional exchange in $\mathrm{Asn}^{7}$ introducing $\mathrm{Phe}$ at this position, a similar residue like the Tyr present on the hPP, yielded [Phe ${ }^{7}$, Pro $\left.^{34}\right]$ pNPY. This is a selective $Y_{1}$ receptor binder and illustrated the importance of an aromatic residue in this position (Soll et al., 2001). Also the combination of Pro $^{34}$ with an exchange in position 31 by Leu contributes to $a Y_{1} / \mathrm{Y}_{4} / \mathrm{Y}_{5}$ receptor selective profile (Fuhlendorff etal., 1990; Cabrele et al., 2000). All this strongly indicates the importance of $\mathrm{N}$ - and C-terminal fragments for the $\mathrm{Y}_{1}$ receptor subtype.

The synthesis of small selective ligands has also been a topic of interest in the past years and many peptides have been synthesized and characterized. Although the first experiments with shortor medium-sized pNPY truncations showed low binding affinity at the $\mathrm{hY}_{1}$ receptor, in recent years several short antagonists, mimicking the NPY C-terminus have been synthesized such as, GR231118 (1229U91 or GW1229), T-241, and T-190. Unfortunately, these ligands also have $\mathrm{Y}_{4}$ agonistic properties (Figure 2; Parker et al., 1998). Taking the short NPY analog NPY (28-36) and the antagonist GR231118, Zwanziger et al. (2009) designed a set of 19 short peptide analogs. Only $\left[\mathrm{Pro}^{30}, \mathrm{Nle}^{31}, \mathrm{Bpa}^{32}\right.$, Leu $\left.^{34}\right]$ NPY(28-36) displayed $h_{1}$ receptor selectivity and was able to activate the receptor (Figure 1B). Follow-up investigations were made by Hofmann and colleagues (Neuropeptides, accepted) on position 32. The authors could further stabilize the peptide by replacing Bpa by Bip (biphenylalanine) and could switch the activity from $h Y_{1}$ receptor to $h Y_{2} / h Y_{4}$ receptors by introducing an ortho-carbaboranyl moiety. Other small peptide antagonists are BW1911U90 and [ $\left.\left.{ }^{32-34} \beta A C C\right]-N P Y(25-36)\right]$; Figure 2; Koglin et al., 2003), and examples of known non-peptidic antagonists are BIBP3226, BIBO3304, LY357897, J-104870 (Figure 4A; Rudolf et al., 1994; Hipskind et al., 1997; Wieland et al., 1998; Sjodin et al., 2006; Antal-Zimanyi et al., 2008).

\section{$Y_{2}$ RECEPTOR}

As with the human $\mathrm{Y}_{1}$ receptor, the $\mathrm{Y}_{2}$ receptor binds NPY and PYY with comparable affinities. Beside these two native highaffinity ligands, a number of $\mathrm{Y}_{2}$-selective NPY-derived peptide

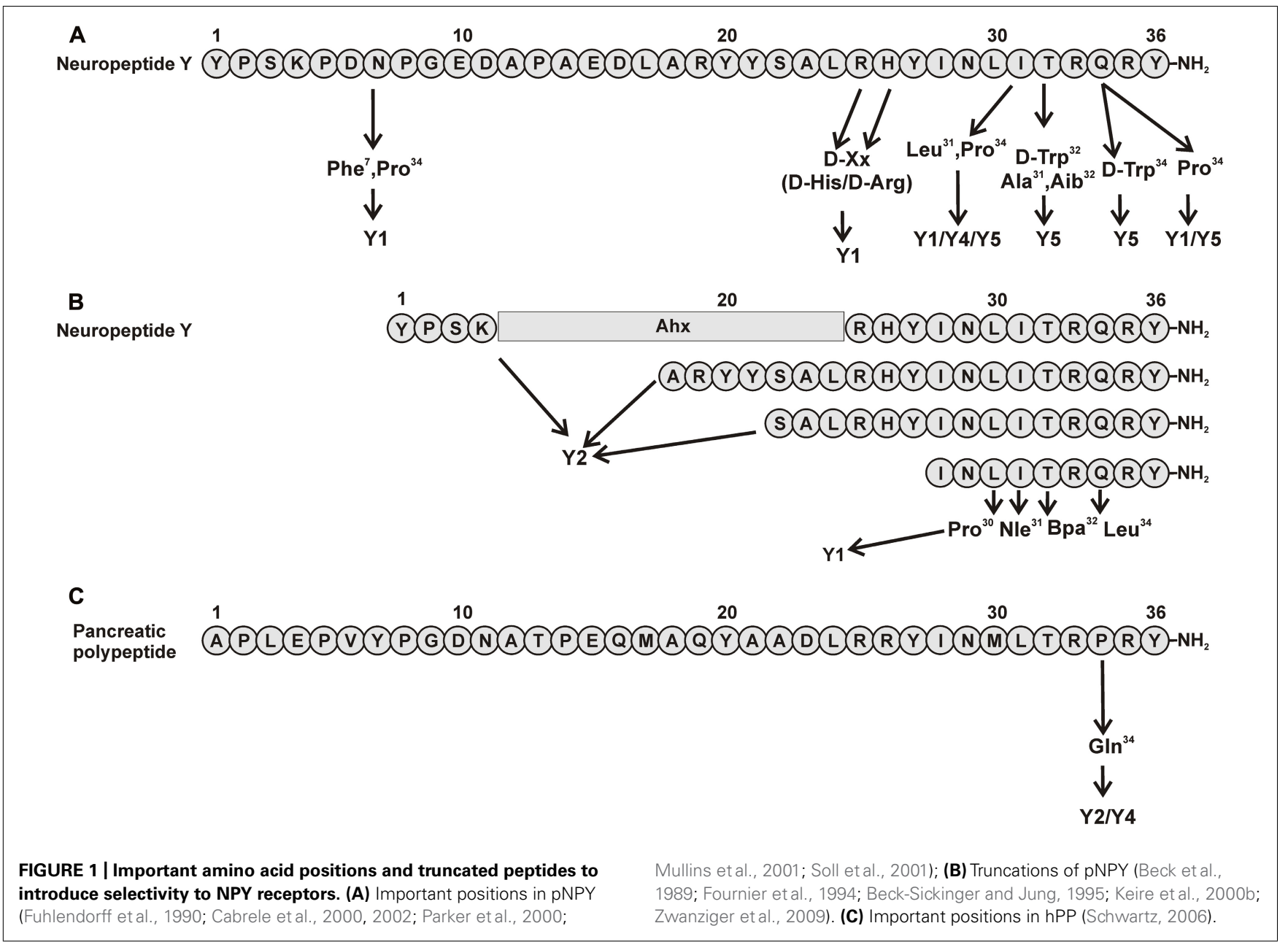




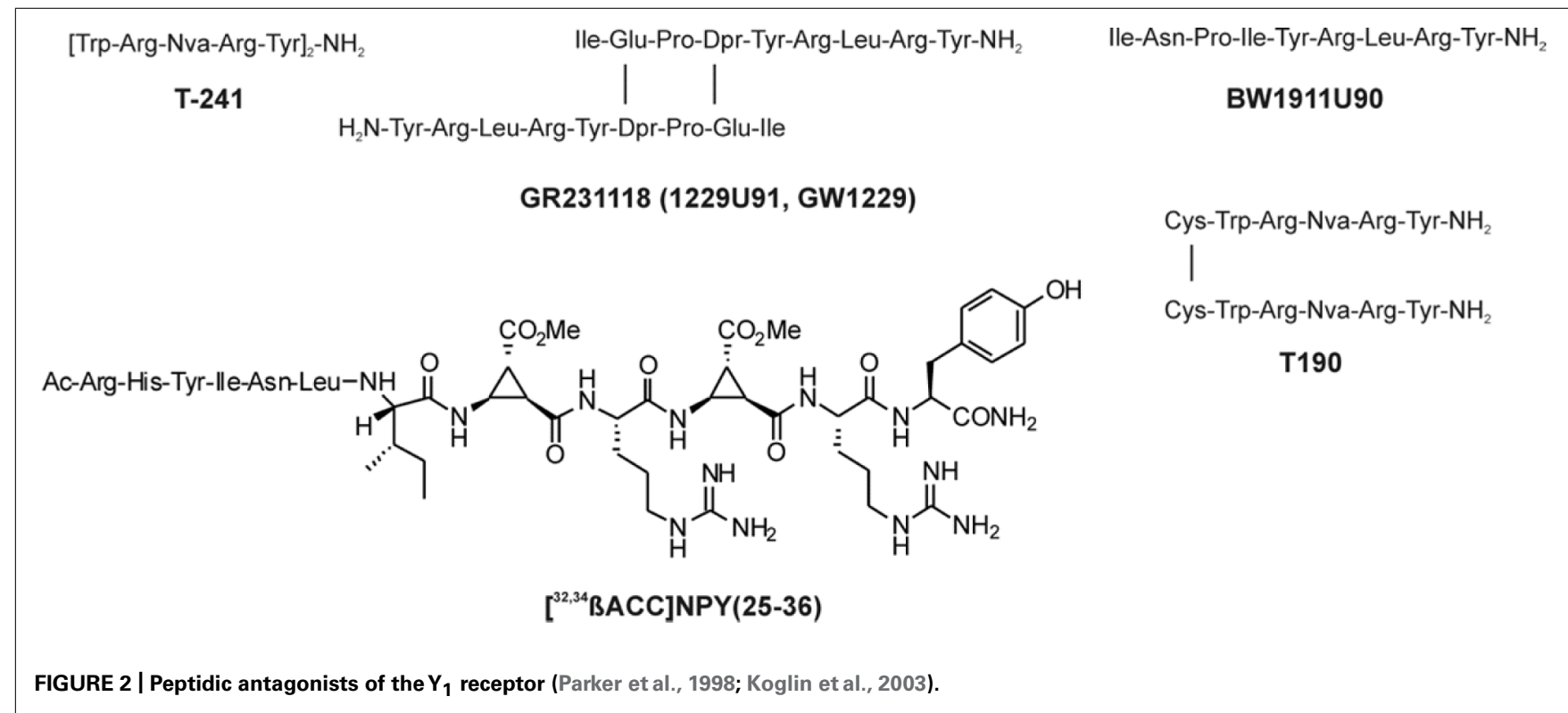

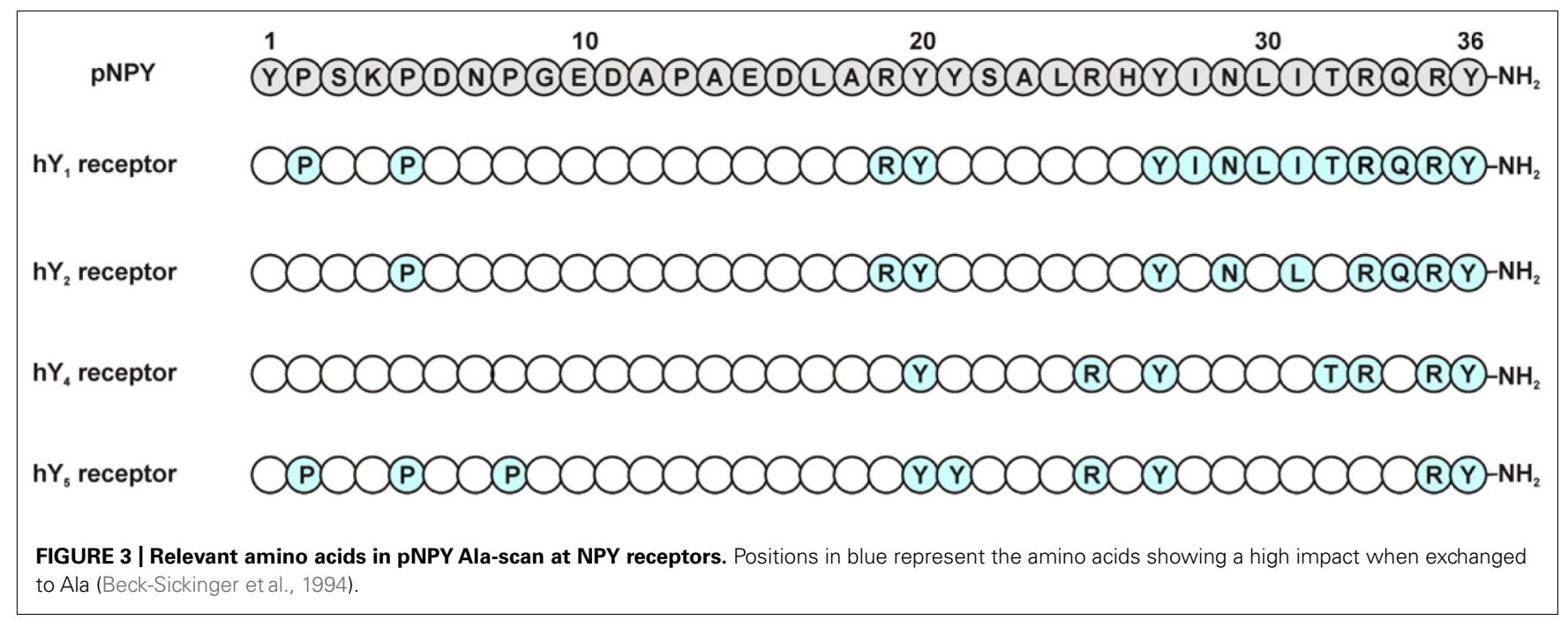

agonists have been synthesized in the past. Interestingly, in contrast to all other $\mathrm{Y}$ receptors, $\mathrm{Y}_{2}$ receptors allow large truncations of the peptidic ligands without loss of affinity (Beck-Sickinger and Jung, 1995) and also cyclizations between N- and C-terminally located residues are tolerated (Kirby et al., 1993b). Most commonly used $\mathrm{Y}_{2}$ receptor selective $\mathrm{NPY}$-analogs are the $\mathrm{N}$-terminally truncated NPY(3-36) and NPY(13-36). Even larger N-terminal truncations and centrally truncated analogs can bind to the $\mathrm{Y}_{2}$ receptor with nanomolar affinity [e.g., NPY(18-36), NPY(22-36), [Ahx ${ }^{5-24}$ ]NPY; Figure 1B; Beck et al., 1989; Fournier et al., 1994; Beck-Sickinger and Jung, 1995; Keire et al., 2000b]. An Ala-scan of the complete NPY peptide revealed only few positions to be highly important (Figure 3).

The substitution of Pro $^{5}$ to Ala led to a 600 -fold loss of affinity. Accordingly, all other important residues except Pro $^{5}$ are located in the C-terminal part of NPY. The individual substitution of $\operatorname{Arg}^{19}, \mathrm{Tyr}^{20}, \mathrm{Tyr}^{27}$, and Asn ${ }^{29}$ in the NPY peptide showed a 30- to 40-fold lower affinity. A more dramatic effect could be observed for the residues Leu ${ }^{31}$ (1000-fold lower affinity), $\operatorname{Arg}^{33}$ (1350fold), $\mathrm{Gln}^{34}$ (150-fold), $\mathrm{Arg}^{35}$ (75000-fold), and $\mathrm{Tyr}^{36}$ (17500-fold; Figure 3; Cabrele and Beck-Sickinger, 2000; Eckard et al., 2001). Interestingly, the introduction of a Pro residue at position 34 is not tolerated at the $\mathrm{Y}_{2}$ receptor, which is in contrast to the effect observed on the other $\mathrm{Y}$ receptor subtypes (Beck-Sickinger et al., 1994; Keire et al., 2000b; Eckard et al., 2001). Although Tyr ${ }^{36}$ may not be substituted by Ala, the introduction of Hty (homotyrosine) or p-substituted Phe in PYY(3-36) is well tolerated at the $\mathrm{Y}_{2}$ receptor, but almost completely abolishes binding of the modified NPY analogs at $Y_{1}$ or $Y_{4}$ receptors (Pedersen et al., 2009). Taken together, these data underline the importance of the Cterminal part of the peptide ligand for high-affinity binding to the $\mathrm{Y}_{2}$ receptor, despite the fact that the binding pocket for NPY at the $Y_{2}$ receptor seems to be less narrow than the ones of $Y_{1}$ or $Y_{4}$ receptors. 


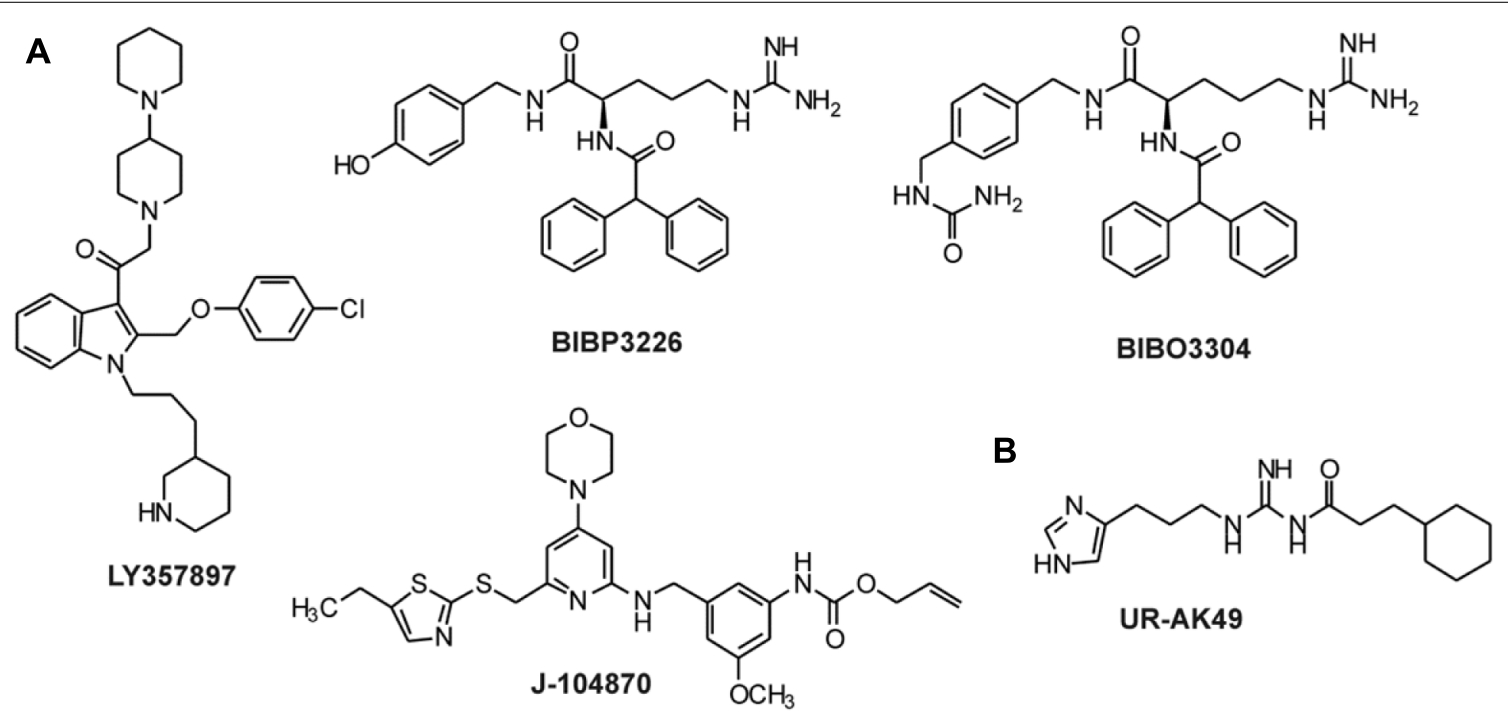

FIGURE 4 | Non-peptidic antagonists for $\mathbf{Y}_{\mathbf{1}}$ and $\mathbf{Y}_{\mathbf{4}}$ receptors. (A) Antagonists for the $\mathrm{Y}_{1}$ receptor (Rudolf et al., 1994; Hipskind et al., 1997; Wieland et al., 1998; Balasubramaniam et al., 2001; Sjodin et al., 2006; Antal-Zimanyi etal., 2008); (B) Antagonists for the $Y_{4}$ receptor (Ziemek et al., 2007).

A number of selective high-affinity antagonists at the $\mathrm{Y}_{2}$ receptor have been published so far. The most widely used compound in pharmacological studies is BIIE0246 (Figure 5A; Doods et al., 1999). In order to identify compounds with improved biostability, bioavailability, and brain permeability, further studies have been conducted. A number of molecules and scaffolds have been reported as highly selective and affine small molecule $\mathrm{Y}_{2}$ receptor antagonists (Figure 5A) including JNJ-527787 (Bonaventure et al., 2004; Jablonowski et al., 2004), SF-11, SF-21, SF-22, SF-31,
SF-41 (Brothers et al., 2010), ML072 to ML075 (Saldanha et al., 2009), JNJ-31020028 (Shoblock et al., 2010; Swanson et al., 2011), a series of substituted 3-chloranilides (Lunniss et al., 2009, 2010), CYM 9484, and CYM 9552 (Mittapalli et al., 2012).

\section{$Y_{4}$ RECEPTOR}

The Ala-scan of the NPY (Eckard et al., 2001) revealed that again $\mathrm{Arg}^{33}$ and $\mathrm{Arg}^{35}$ are crucial for receptor affinity. Ala substitutions in these positions led to a dramatic loss in binding. Positions<smiles>CCN(CC)C(=O)C(c1ccccc1)N1CCN(c2ccc(NC(=O)c3ccccc3-c3cccnc3)cc2F)CC1</smiles>

\section{B}<smiles>CCCCCCCCCOc1ccc(NC(=S)NC)cc1</smiles>

SF-11<smiles>CC1(C)CC(=O)C(C2C(=O)CC(C)(C)CC3=C2CC(C)(C)O3)=C(O)C1</smiles><smiles>CC(C)n1c2c(c3cc(NC(=O)N(C)CCc4ccncc4)ccc31)CCCC2</smiles>

FMS586<smiles>Nc1nc(NCC2CCC(CNS(=O)(=O)c3cccc4ccccc34)CC2)nc2ccccc12</smiles>

FIGURE 5 | Non-peptidic antagonists of $\mathbf{Y}_{\mathbf{2}}$ and $\mathbf{Y}_{\mathbf{5}}$ receptors. (A) $\mathbf{Y}_{2}$ receptor antagonists (Doods et al., 1999; Saldanha et al., 2009; Shoblock et al., 2010; Swanson et al., 2011); (B) Y 5 receptor antagonists (Criscione et al., 1998; Kanatani et al., 2000a; Rueeger et al., 2000; Kakui et al., 2006). 
$\operatorname{Tyr}^{20}, \operatorname{Tyr}^{27}, \mathrm{Arg}^{25}, \mathrm{Thr}^{32}$, and $\mathrm{Tyr}^{36}$ are also important residues in the ligand and showed a loss in binding affinity (30- to 60-fold), whereas Pro $^{5}$, Pro $^{8}$, and Tyr $^{21}$ proved to be less relevant, causing only a slight loss in affinity (5- to 10-fold) when changed to Ala (Figure 3).

In a follow-up study using hPP (Merten et al., 2007), Arg residues 33 and 35 were confirmed to be essential for receptor activation, showing a dramatic effect when exchanged to Ala in position 33. Position $\mathrm{Arg}^{35}$ was found to interact with $\mathrm{Asp}^{6.59}$ of the receptor.

Because this receptor subtype has its own selective ligand, peptide research is more focused on improving proteolytic stability and increasing bioavailability of the peptide. However, a number of specific ligands have been published in the past years for this receptor. As previously described, position 34 of NPY peptides is a key residue to introduce $\mathrm{Y}_{4}$ receptor selectivity to NPY and PYY, whereas in PP when exchanging Pro ${ }^{34}$ for Gln the peptide acquires $\mathrm{Y}_{2}$ agonistic properties without losing $\mathrm{Y}_{4}$ receptor activity. Some of the analogs published like $\left[\mathrm{Gln}^{34}\right]$-hPP, the so called Obinepitide (Schwartz, 2006), which is selective for $\mathrm{Y}_{2}$ and $\mathrm{Y}_{4}$ receptors, contains this exchange (Figure 1C). Other small peptide agonists described also as $\mathrm{Y}_{1}$ receptor antagonists are: GR231118 (1229U91 or GW1229), T-241, and T-190 (Figure 2; Schober et al., 1998).

To our knowledge, only one ligand with antagonistic properties at the $\mathrm{hY}_{4}$ receptor has been published up to now. UR-AK49 (Figure 4B) is a weak $\mathrm{hY}_{4}$ receptor antagonist but unselective, because it can also bind to $\mathrm{hY}_{1}$ and $\mathrm{hY}_{5}$ receptors (Ziemek et al., 2007).

\section{$Y_{5}$ RECEPTOR}

The $\mathrm{hY}_{5}$ receptor subtype does not tolerate large truncations of NPY. While the deletion of the first amino acid is accepted by the $\mathrm{hY}_{5}$ receptor, further N-terminal truncation of NPY results in a decreased affinity of the peptides. Similarly, larger central truncations of NPY are not tolerated by $\mathrm{Y}_{5}$ receptors. The only centrally truncated analog of NPY with high $\mathrm{Y}_{5}$ receptor affinity is [Ahx ${ }^{9-17}$ ]pNPY with a $\sim 15$-fold decreased affinity compared to pNPY (Cabrele and Beck-Sickinger, 2000).

An Ala scan of the complete peptide revealed the Pro residues 2, 5, and 8 to be important for the affinity of NPY at the $\mathrm{Y}_{5}$ (Figure 3). Haack et al. (2008) could confirm the importance of the peptide $\mathrm{N}$-terminus for high-affinity binding at the $\mathrm{Y}_{5}$ receptor by a pyridone dipeptide scan. In addition to these findings, the individual substitution of Tyr residues 20, 21, 27, and 36 to Ala led to a loss of affinity; $\operatorname{Arg}^{25}$ was also shown to be important for the ligand affinity. The highest impact could be observed for $\mathrm{Tyr}^{27}$ ( $\sim 400$-fold) and $\mathrm{Arg}^{35}$ (1000-fold; Cabrele and Beck-Sickinger, 2000), these findings fit with the fact that these two positions are involved in interactions with the receptor.

A number of selective high-affinity analogs of NPY and PYY have been developed in the past. It has been shown that especially the substitution of position 32 of the peptide ligands is critical for $\mathrm{Y}_{5}$ selectivity (Figure 1A). [D-Trp $\left.{ }^{32}\right] \mathrm{NPY}$ and $\left[\mathrm{Ala}^{31}\right.$, $\mathrm{Aib}^{32}$ ]NPY have been reported to be highly selective and potent agonists of $\mathrm{Y}_{5}$ receptor (Parker et al., 2000; Cabrele et al., 2002). However, the most potent and selective activator of the $\mathrm{Y}_{5}$ receptor subtype is a chimeric peptide derived from chicken PP, human NPY, and human PP ([ $\mathrm{cPP}^{1-7}, \mathrm{NPY}^{19-23}$, $\left.\mathrm{His}^{34}\right]$ hPP; Cabrele and Beck-Sickinger, 2000). In addition, $\mathrm{Y}_{5}$ receptors display high-affinity to some NPY analogs which also have a considerable affinity for other $\mathrm{Y}$ receptor subtypes. [Leu ${ }^{31}, \mathrm{Pro}^{34}$ ]pNPY is a $\mathrm{Y}_{1} / \mathrm{Y}_{4} / \mathrm{Y}_{5}$ selective agonist (Fuhlendorff et al., 1990; Widdowson etal., 1997), whereas the deletion of the first Tyr residue results in the $\mathrm{Y}_{2} / \mathrm{Y}_{5}$ selective agonist NPY (2-36) (Gerald et al., 1996).

Since NPY has been shown to stimulate feeding via the $\mathrm{Y}_{5}$ receptor, intensive research has been performed to identify small molecule antagonists of the human $\mathrm{Y}_{5}$ receptor as potential feeding suppressors. The first compound that was published as an antagonist of $\mathrm{Y}_{5}$ receptor was CGP71683A (Figure 5B), which displayed high-affinity and selectivity at the $\mathrm{rY}_{5}$ receptor (Criscione et al., 1998). Later studies confirmed the high-affinity and selectivity also for the $\mathrm{hY}_{5}$ receptor subtype (Rueeger et al., 2000). Other selective small antagonists at the human $\mathrm{Y}_{5}$ receptor include L152,804 (Kanatani et al., 2000a), FMS586 (Kakui et al., 2006), MK-0557 (Erondu et al., 2007), and SCH 500946 (Mullins et al., 2008). In the last 5 years, more than 10 studies have been published presenting newly identified or improved small molecule antagonists of the $\mathrm{Y}_{5}$ receptor. This clearly shows the importance of the $\mathrm{Y}_{5}$ receptor as an anti-obesity target.

\section{HOW TO IDENTIFY RELEVANT RESIDUES ON THE RECEPTOR FOR BINDING AND SUBTYPE SELECTIVITY GENERAL STRATEGIES}

As these receptors consist of $350-450$ residues it is impossible to perform a single mutagenesis approach to investigate each amino acid. In order to overcome this problem chimeric receptors can be used, in which fragments of a receptor (e.g., extracellular loops or transmembrane helices) can be exchanged between receptor subtypes. Testing these new constructs with the main agonist from both receptor subtypes can provide information about the importance of one or the other segment, in terms of interaction with the ligand. As soon as an important area in a receptor has been identified, a more detailed study can be carried out using single and multiple mutants, where certain residues of a receptor subtype are exchanged by the ones present on the other receptor subtype of investigation. This strategy allows to find amino acids that may play a role in selectivity to a certain agonist.

When investigating the relevance of the N-terminus, successive truncations or substitutions using tags or spacers can be an elegant method. Furthermore, C-terminal truncations can provide information about segments relevant for internalization. It is known that this receptor part is involved in arrestin-dependent internalization processes of $\mathrm{Y}_{1}, \mathrm{Y}_{2}$, and $\mathrm{Y}_{5}$ receptors (Walther et al., 2011). However, single mutagenesis techniques can be used to investigate important residues for the structure or for ligand receptor interactions. Using this approach, certain residues located in extracellular areas of the protein are mutated to Ala or other amino acids in single substitutions. The residues can be chosen according to its location, charge, aromaticity, hydrophobicity. Moreover, 3-D models are also a good tool to select new targets, although mutagenesis data are needed to refine the models and make them more reliable. Once a relevant residue has been identified, double 
cycle mutagenesis can be used to find the type of interaction that includes both positions. In this technique, peptide analogs containing modifications in positions of interest are investigated with receptor mutants. The aim is to form artificial bonds to proof a native interaction. The introduction of charged residues in the peptide and receptor positions to create a repulsion/attraction, or aromatic residues and hydrophobic residues are feasible ways to prove a ligand receptor interaction. In order to finally prove a ligand-receptor interaction, a reciprocal mutation approach can be followed, where the residue of interest on the peptide side is exchanged by the residue present on the receptor side and vice versa. In the case of a critical position or segment, the binding affinity of the native ligand should significantly decrease, whereas in signal transduction assays the $\mathrm{EC}_{50}$ or half maximal activation value should increase. Despite all the advantages that these approaches provide, it has to be taken into account that they also present some disadvantages. Thus, when constructing receptor chimeras or receptor mutants, alterations in the receptor structure may arise due to misfolding and therefore may lead to impaired receptor export. Moreover, these modifications might result in a reduced receptor retention time at the cell surface and an enhanced degradation. All together, this might lead to a loss in binding or receptor activity. In order to analyze such phenomena, fluorescence microscopy, cell surface ELISA or radioligand binding studies are a good tool to ensure cell surface expression.

\section{$\mathbf{Y}_{\mathbf{1}}$ RECEPTOR}

In the past years, much effort has been made to characterize this receptor. Using $\mathrm{N}$-terminal truncations and receptor chimera, it could be elucidated that the N-terminal part of NPY receptors does not participate in the binding pocket. N-terminal truncation in the $\mathrm{hY}_{1}$ receptor disrupts the membrane expression; however any eight residues are enough to recover the membrane expression (Lindner et al., 2009).

From all these studies, a number of residues emerged as important for the receptor. First of all, two negatively charged residues are able to establish electrostatic interaction. Asp ${ }^{2.68}$ and $\mathrm{Asp}^{6.59}$ were found to be important for the receptor as the peptide loses affinity when mutated to Ala (Sautel et al., 1995, 1996; Kannoa et al., 2001; Sjodin et al., 2006). Furthermore Asp ${ }^{6.59}$ was shown to bind $\mathrm{Arg}^{35}$ of pNPY being the first and only proved interaction for this receptor (Merten et al., 2007). Other residues that appeared to be important in several studies are $\mathrm{Tyr}^{2.64}, \mathrm{Phe}^{6.58}$, and His ${ }^{7.31}$ (Sautel et al., 1995, 1996; Kannoa et al., 2001; Sjodin et al., 2006), although a direct interaction was never established for any of the amino acids of the ligand. It was suggested that these residues form a hydrophobic pocket in the receptor. Further investigations using the $\mathrm{Y}_{1}$ receptor antagonist BIBP 3226 showed that $\mathrm{Tyr}^{2.64}$ and His ${ }^{7.31}$ did not affect the conformation of the receptor in a major way (Sautel et al., 1996) as the antagonist was perfectly bound. Taken together, it is very likely that position 6.58 and 7.31 interact with a C-terminally located amino acid, on the other hand it is unlikely that $\mathrm{Tyr}^{2.64}$ interacts with the C-terminus as it seems to be too far from the other two residues.

Other relevant residues of the receptor are $\operatorname{Trp}^{6.60}$, Asn $^{6.55}$, and $\mathrm{Asn}^{7.32}$ (Kannoa et al., 2001). Although position 6.55 is in a slightly deeper position, Asn ${ }^{6.55}$ and Asn ${ }^{7.32}$ showed a loss in PYY binding and also in antagonist binding suggesting that they could play a role in ligand binding (Figure 6A).

Studies with antagonists indicate that the binding of these compounds differs depending on the ligand between transmembrane helices 3 and 7. Taking all the data into consideration, it can be assumed that the binding pattern of the native ligands and the small antagonists overlaps in TM6 because several residues have been found to be relevant in both cases.

\section{$Y_{2}$ RECEPTOR}

In this receptor subtype, the $\mathrm{N}$-terminus does not play a role in membrane expression and it does not participate in a subtype specific binding pocket. However, it does play a role in agonist induced internalization processes since the complete truncation slowed down the process, although it could be seen that the exchange of the N-terminal fragment by the $\mathrm{hY}_{1}$ receptor or $\mathrm{hY}_{5}$ receptor fragment did not affect ligand dependent internalization (Lindner et al., 2009).

Mutagenesis studies to identify residues that contribute to ligand binding in the $\mathrm{Y}_{2}$ receptor were initially motivated by the finding that human and chicken $\mathrm{Y}_{2}$ receptors show a significantly different pharmacological profile. The chicken $\mathrm{Y}_{2}$ receptor is able to bind [ $\left.\mathrm{Leu}^{31}, \mathrm{Pro}^{34}\right]$-NPY, a peptide agonist selective for mammalian $\mathrm{Y}_{1} / \mathrm{Y}_{4} / \mathrm{Y}_{5}$ receptors, but was unable to bind BIIE0246, a small molecule antagonist for mammalian $\mathrm{Y}_{2}$ receptors (Salaneck et al., 2000). Sequence comparison and reciprocal mutagenesis revealed three residues in transmembrane helices 3, 5, and 6 that contribute to the binding of BIIE0246. Individual and combined substitution of $\mathrm{Gln}^{3.37}$, $\mathrm{Leu}^{5.51}$, and $\mathrm{Leu}^{6.51}$ in the $\mathrm{hY}_{2}$ receptor decreased the affinity for BIIE0246 to a $\mathrm{chY}_{2}$-like level, whereas substitution of the corresponding residues in the $\mathrm{chY}_{2}$ by the human residues increased the affinity for BIIE0246 (Berglund et al., 2002). Further mutagenesis studies on the human $\mathrm{Y}_{2}$ receptor revealed interaction partners for the native peptidic ligand NPY. Several acidic residues have been tested for their importance for NPY binding. Glu ${ }^{5.27}$ and $\mathrm{Asp}^{6.59}$ turned out to be highly important for the binding of NPY (Figure 6C). While Asp ${ }^{6.59}$ is important for all Y receptor subtypes, $\mathrm{Glu}^{5.27}$ only plays a role in the $\mathrm{Y}_{2}$ receptor. Both receptor mutants were tested in a signal transduction assay using pNPY, $\left[\mathrm{Ala}^{25}\right]$ pNPY, $\left[\mathrm{Ala}^{33}\right]$ pNPY, and $\left[\mathrm{Ala}^{35}\right] \mathrm{pNPY}$ to identify the interaction partner of the two acidic residues in the peptide. It could be shown that $\mathrm{Asp}^{6.59}$ interacts with $\mathrm{Arg}^{33}$ of the peptidic ligand in the $\mathrm{Y}_{2}$ and $\mathrm{Y}_{5}$ receptors, whereas the interaction partner in $\mathrm{Y}_{1}$ and $\mathrm{Y}_{4}$ receptors is $\mathrm{Arg}^{35}$. However, no direct interaction partner could be identified for $\mathrm{Glu}^{5.27}$ (Merten et al., 2007). More recent studies investigated additional residues in the $\mathrm{Y}_{2}$ receptor for their impact on the binding of pPYY, pNPY, hPYY (3-36), pNPY(13-36), and the nonpeptidic antagonist BIIE0246 (Akerberg et al., 2010; Fallmar et al., 2011). The residues tested, namely $\mathrm{Tyr}^{2.64}, \mathrm{Gly}^{2.68}, \mathrm{Thr}^{3.40}$, $\mathrm{Leu}^{4.60}, \mathrm{Gln}^{6.55}, \mathrm{Val}^{6.58}$, and $\mathrm{Tyr}^{7.31}$, were chosen by similarity to residues in the $\mathrm{Y}_{1}$ receptor subtype, which were proven to be important for ligand binding in this receptor subtype. It could be shown, that of the tested residues, only $\mathrm{Tyr}^{2.64}$ participates in the binding of all tested peptidic ligands and 


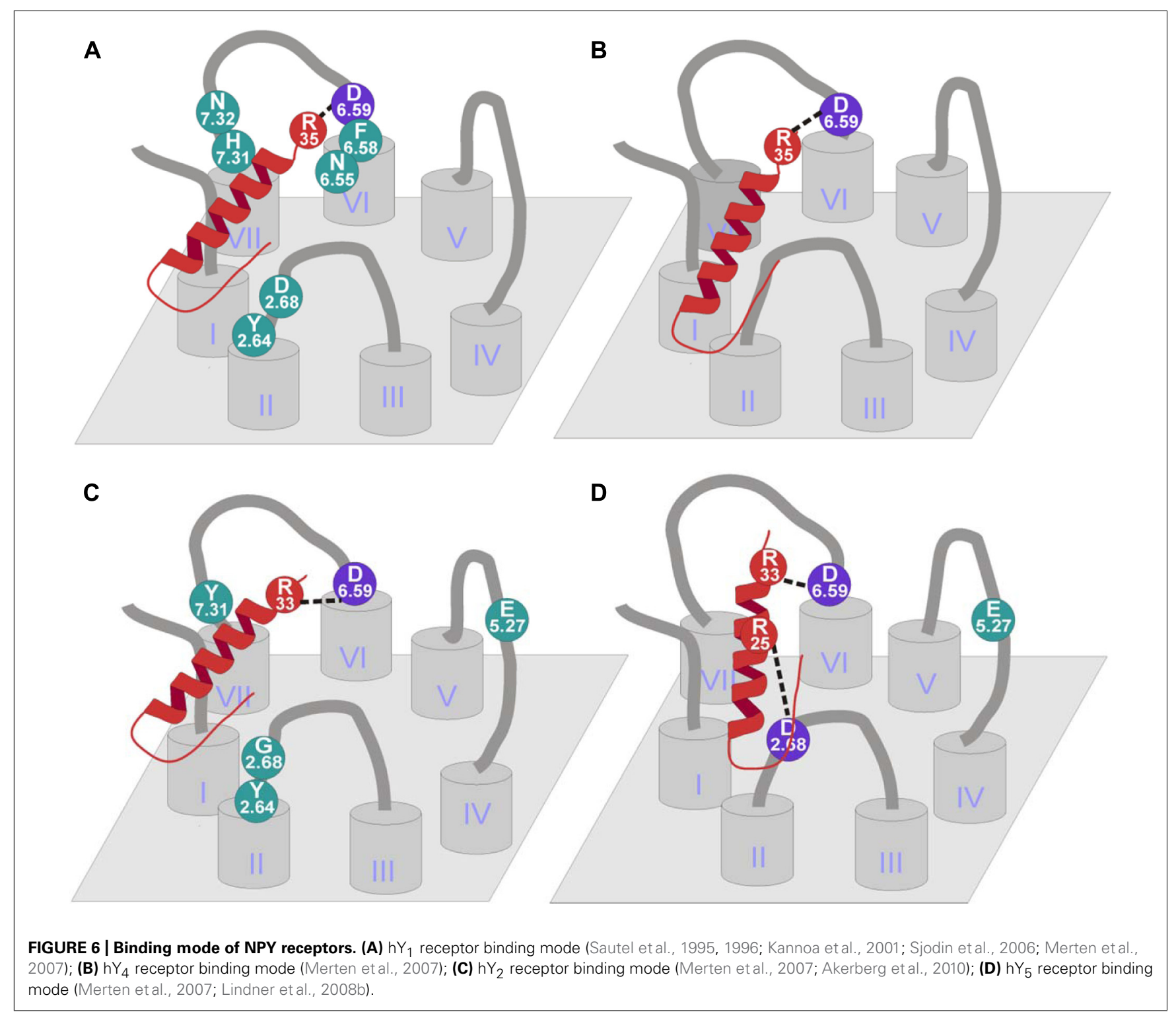

the non-peptidic antagonist BIIE0246. The substitution of this residue to Ala resulted in a five- to ninefold reduction in affinity (Akerberg et al., 2010).

The individual substitution of $\mathrm{Tyr}^{7.31}$ by Ala and Gly ${ }^{2.68}$ by the bigger and more polar residue Asn revealed a lower affinity only for the truncated peptide agonists. The authors hypothesize that $\mathrm{Tyr}^{7.31}$ does not play a role in binding of the full-length peptide, but may contribute to a compensatory interaction for ligands that lack the N-terminal residues. Furthermore, the authors could show that an introduction of a His residue in position 7.31 (the corresponding residue in $\mathrm{Y}_{1}$ receptor) completely abolished the binding of $\left[{ }^{125} \mathrm{I}\right]$-pPYY (Akerberg et al., 2010). These findings are somewhat unexpected, since this His residue was shown to be involved in ligand binding in the $\mathrm{Y}_{1}$ receptor (Sjodin et al., 2006). This indicates that position 7.31 is important in both receptor subtypes, but may have different modes of action (Akerberg et al., 2010). For position 2.68, a mode of binding is proposed in which the lack of Asp (a residue common to all other Y receptor subtypes at this position) contributes to the selectivity of truncated peptides [e.g., NPY(3-36)] for the $\mathrm{Y}_{2}$ receptor (Fallmar et al., 2011). The Leu ${ }^{4.60}$ Ala mutant showed a slightly decreased affinity for hPYY(3-36) and a strong loss of affinity for BIIE0246, which may be caused by a weakened or lost hydrophobic interaction. This indicates that this residue is highly important for antagonist binding. The corresponding position in $\mathrm{Y}_{1}$ receptor $\left(\mathrm{Phe}^{4.60}\right)$ has been shown to be involved in the binding of $\left[{ }^{125} \mathrm{I}\right] \mathrm{NPY}$, $\left[{ }^{3} \mathrm{H}\right] \mathrm{BIBP} 3226$ (Sautel et al., 1996) as well as $\left[{ }^{3} \mathrm{H}\right] \mathrm{J}-104870$ (Kannoa et al., 2001). This indicates that position 4.60 is involved in the binding of small molecule antagonists at both receptor subtypes, $\mathrm{Y}_{1}$ and $\mathrm{Y}_{2}$.

The $\mathrm{Y}_{2}$ receptor mutants $\mathrm{Thr}^{3.40}$ Ile and $\mathrm{Gln}{ }^{6.55} \mathrm{Ala}$ showed increased affinity for pNPY and hPYY(3-36), but decreased affinity for the non-peptidic antagonist BIIE0246. Taken into account that these positions are located deeper in the transmembrane part 
of the receptor, an indirect effect on the binding of peptidic ligands would be the most likely explanation. However, the decreased binding of BIIE0246 may be also explained by a different binding pocket for small molecule antagonists, located more deeply in the transmembrane (Fallmar et al., 2011) and surrounded not only by $\mathrm{Thr}^{3.40}$ and $\mathrm{Gln}{ }^{6.55}$, but also by the nearby residue $\mathrm{Gln}^{3.37}$, which was earlier shown to participate in the binding of BIIE0246 earlier (Berglund et al., 2002).

\section{$\mathbf{Y}_{4}$ RECEPTOR}

$\mathrm{N}$-terminal truncations and substitutions revealed the importance of this fragment for membrane expression and indicated that the $\mathrm{N}$-terminus is not involved in forming a specific binding pocket. It is likely that this part could stabilize the TM1 to ensure the correct receptor structure (Lindner et al., 2009).

Two positions were investigated to find the binding partners on the ligand side (Merten et al., 2007). Glu ${ }^{5.24}$ was mutated to Ala in order to test the influence of the side chain, $\mathrm{Glu}^{5.24}$ Ala showed a threefold loss in potency. On the other hand, Asp ${ }^{6.59}$ was mutated to Ala, Glu, Asn, and Arg to test the influence of charge and length of the side chain. The mutation to Ala showed a complete loss of both binding and activity, the exchange to Glu displayed wildtype-like binding and activation. In addition, the mutation to Asn showed indeterminate binding and a 200 -fold loss in activation. Finally the exchange to Arg resulted in a dramatic loss in potency (>600-fold) and in no detectable binding (Figure 6B).

\section{$Y_{5}$ RECEPTOR}

The $\mathrm{Y}_{5}$ subtype $\mathrm{N}$-terminus could play a role in ligand binding, since the partial truncation of the segment produced a loss in activation. Interestingly, the receptor remains on the membrane even when the complete N-terminus is removed (Lindner et al., 2009).

Only few mutagenesis studies have been published so far for the human $\mathrm{Y}_{5}$ receptor. Merten et al. (2007) exchanged three acidic residues in the extracellular domains of $\mathrm{Y}_{5}$ receptor. While the Asp ${ }^{6.62}$ Ala mutant showed wild-type-like pharmacological properties, Asp ${ }^{6.59} \mathrm{Ala}$ and $\mathrm{Glu}^{5.27} \mathrm{Ala}$ displayed a dramatically reduced affinity for NPY. Additional residues were investigated by Lindner et al. (2008b), resulting in identification of a third acidic residue $\left(\mathrm{Asp}^{2.68}\right)$ which is important for ligand binding at the $\mathrm{Y}_{5}$ receptor. These Ala-mutants have also been tested with NPY analogs in which the $\mathrm{Tyr}^{27}, \mathrm{Tyr}^{36}$, and the Arg residues at position 25, 33, and 35 were individually substituted by Ala (Figure 6D). This approach revealed no further loss of affinity for $\left[\mathrm{Ala}^{33}\right] \mathrm{pNPY}$ on the $\mathrm{Asp}^{6.59} \mathrm{Ala}$ mutant of the receptor, indicating a direct interaction

\section{REFERENCES}

Akerberg, H., Fallmar, H., Sjodin, P., Boukharta, L., Gutierrez-DeTeran, H., Lundell, I., et al. (2010). Mutagenesis of human neuropeptide Y/peptide YY receptor Y2 reveals additional differences to $\mathrm{Y} 1$ in interactions with highly conserved ligand positions. Regul. Pept. 163, 120-129.

Antal-Zimanyi, I., Bruce, M. A., Leboulluec, K. L., Iben, L. G., Mattson, G. K., Mcgovern, R. T., et al. (2008). Pharmacological characterization and appetite suppressive properties of BMS-193885, a novel and selective neuropeptide $\mathrm{Y}(1)$ receptor antagonist. Eur. J. Pharmacol. 590, 224-232.

Asakawa, A., Inui, A., Ueno, N., Fujimiya, M., Fujino, M. A., and Kasuga, M. (1999). Mouse pancreatic polypeptide modulates food intake, while not influencing anxiety in mice. Peptides 20, 1445-1448.

Asakawa, A., Inui, A., Yuzuriha, H., Ueno, N., Katsuura, G., Fujimiya,

between $\mathrm{Ala}^{33}$ of the peptide and $\mathrm{Asp}^{6.59}$ of the receptor. Similarly, $\mathrm{Arg}^{25}$ of the NPY peptide could be identified as the interaction partner for Asp ${ }^{2.68}$ of the receptor (Lindner et al., 2008b).

\section{CONCLUSION AND PERSPECTIVES}

The NPY system has been extensively characterized in the last years. The modulation of actions mediated by the distinct receptors like, e.g., its involvement in obesity, cancer, and epilepsy are of great importance. Therefore, the development of receptor subtype-selective ligands and structure-activity relationship studies have been a major objective in the past years. Primarily, amino acid scans and truncations have identified the important residues and areas of the ligand with respect to binding at each receptor. The Y receptors have been extensively studied, several important residues have been characterized and some of the binding pockets have been partially characterized. Two subtype-selective interactions have been elucidated so far. A similar binding mode has been identified on NPY receptors, where a common residue Asp ${ }^{6.59}$ binds to one of the two C-terminally located Arg of the peptide depending on the receptor subtype. Moreover, a second binding interaction has been found on the $\mathrm{Y}_{5}$ receptor where Asp ${ }^{2.68}$ located at the top of TM2 interacts with $\mathrm{Arg}^{25}$ of the peptide (Merten et al., 2007; Lindner et al., 2008b). This finding would suggest that probably a second interaction could take place in other receptor subtypes. Nevertheless, further investigations have to be performed. It is likely that more interactions between the receptors and the peptides could occur, therefore structure activity relationship studies are still a focus of interest.

The design of short analogs and antagonists have confirmed these findings, indicating that this is a great tool to modulate and study the receptors. Some promising progresses have been achieved in cancer diagnosis using $\mathrm{Y}_{1}$ receptor selective short ligands. However the development of short analogs for treatment of this pathology still remains challenging. Also in anti-obesity drugs, $\mathrm{Y}_{2} / \mathrm{Y}_{4}$ receptor selective agonists are in progress and currently in clinical trials of Phase I/II. On the basis of well studied characteristics accounting for receptor subtype selectivity, it is likely that subsequent investigations could be focused on the improvement of pharmacological properties such as stability and half-life. In addition the development of more potent selective ligands might be a focus of interest.

\section{ACKNOWLEDGMENT}

The financial contribution of the German Research Foundation (DFG) for SFB 610/3, project A1 is kindly acknowledged.

M., et al. (2003). Characterization of the effects of pancreatic polypeptide in the regulation of energy balance. Gastroenterology 124, 1325-1336.

Balasubramaniam, A. (2002). Clinical potentials of neuropeptide $\mathrm{Y}$ family of hormones. Am. J. Surg. 183, 430-434.

Balasubramaniam, A., Dhawan, V. C., Mullins, D. E., Chance, W. T., Sheriff, S., Guzzi, M., et al. (2001). Highly selective and potent neuropeptide Y (NPY) Y1 receptor antagonists based on $[\operatorname{Pro}(30)$, Tyr(32), Leu(34)]NPY(28-36)-NH2 (BW1911U90). J. Med. Chem. 44, 1479-1482.

Baldock, P. A., Lee, N. J., Driessler, F., Lin, S., Allison, S., Stehrer, B., et al. (2009). Neuropeptide Y knockout mice reveal a central role of NPY in the coordination of bone mass to body weight. PLoS ONE 4:e8415. doi: 10.1371/journal.pone.0008415

Baldock, P. A., Sainsbury, A., Couzens, M., Enriquez, R. F., Thomas, G. 
P., Gardiner, E. M., et al. (2002). Hypothalamic Y2 receptors regulate bone formation. J. Clin. Invest. 109, 915-921.

Bard, J. A., Walker, M. W., Branchek, T. A., and Weinshank, R. L. (1995). Cloning and functional expression of a human Y4 subtype receptor for pancreatic polypeptide, neuropeptide Y, and peptide YY. J. Biol. Chem. 270, 26762-26765.

Beck-Sickinger, A. G. (1997). "Synthesis of conformationally restricted peptides," in Neuropeptide Protocols, eds G. Brent Irvine and Carvell H. Williams (Totowa, NJ: Humana Press), 61-74.

Beck-Sickinger, A. G., and Jung, G. (1995). Structure-activity relationships of neuropeptide $\mathrm{Y}$ analogues with respect to $\mathrm{Y} 1$ and Y2 receptors. Biopolymers 37, 123-142.

Beck-Sickinger, A. G., Wieland, H. A., Wittneben, H., Willim, K. D., Rudolf, K., and Jung, G. (1994). Complete L-alanine scan of neuropeptide $\mathrm{Y}$ reveals ligands binding to $\mathrm{Y} 1$ and Y2 receptors with distinguished conformations. Eur. J. Biochem. 225, 947-958.

Beck, A., Jung, G., Gaida, W., Koppen, H., Lang, R., and Schnorrenberg, G. (1989). Highly potent and small neuropeptide $\mathrm{Y}$ agonist obtained by linking NPY 1-4 via spacer to alphahelical NPY 25-36. FEBS Lett. 244, 119-122.

Berglund, M. M., Fredriksson, R., Salaneck, E., and Larhammar, D. (2002). Reciprocal mutations of neuropeptide $\mathrm{Y}$ receptor $\mathrm{Y} 2$ in human and chicken identify amino acids important for antagonist binding. FEBS Lett. 518, 5-9.

Blomqvist, A. G., and Herzog, H. (1997). Y-receptor subtypes - how many more? Trends Neurosci. 20, 294-298.

Blomqvist, A. G., Soderberg, C., Lundell, I., Milner, R. J., and Larhammar, D. (1992). Strong evolutionary conservation of neuropeptide Y: sequences of chicken, goldfish, and Torpedo marmorata DNA clones. Proc. Natl. Acad. Sci. U.S.A. 89, 2350-2354.

Blundell, T. L., Pitts, J. E., Tickle, I. J., Wood, S. P., and Wu, C. W. (1981). X-ray analysis (1. 4-A resolution) of avian pancreatic polypeptide: small globular protein hormone. Proc. Natl. Acad. Sci. U.S.A. 78, 4175-4179.

Boguszewski, C. L., Paz, G., and Velloso, L. A. (2010). Neuroendocrine body weight regulation: integration between fat tissue, gastrointestinal tract, and the brain. Endokrynol. Pol. 61, 194-206.

Bonaventure, P., Nepomuceno, D. Mazur, C., Lord, B., Rudolph, D A., Jablonowski, J. A., etal. (2004). Characterization of $\mathrm{N}$-(1-Acetyl2,3-dihydro-1H-indol-6-yl)-3-(3cyano-phenyl)- $N$-[1-(2-cyclopentylethyl)-piperidin-4yl] acrylamide

(JNJ-5207787), a small molecule antagonist of the neuropeptide Y Y2 receptor. J. Pharmacol. Exp. Ther 308, 1130-1137.

Bonini, J. A., Jones, K. A., Adham, N., Forray, C., Artymyshyn, R. Durkin, M. M., et al. (2000). Identification and characterization of two $\mathrm{G}$ protein-coupled receptors for neuropeptide FF. J. Biol. Chem. 275 39324-39331.

Bromee, T., Sjodin, P., Fredriksson, R. Boswell, T., Larsson, T. A., Salaneck, E., et al. (2006). Neuropeptide Y-family receptors Y6 and Y7 in chicken. Cloning, pharmacological characterization, tissue distribution and conserved synteny with human chromosome region. FEBS J. 273, 2048-2063.

Brothers, S. P., Saldanha, S. A., Spicer, T. P., Cameron, M., Mercer, B. A., Chase, P., et al. (2010). Selective and brain penetrant neuropeptide y y2 receptor antagonists discovered by wholecell high-throughput screening. Mol. Pharmacol. 77, 46-57.

Caberlotto, L., Fuxe, K., Sedvall, G., and Hurd, Y. L. (1997). Localization of neuropeptide Y Y1 mRNA in the human brain: abundant expression in cerebral cortex and striatum. Eur. J. Neurosci. 9, 1212-1225.

Cabrele, C., and Beck-Sickinger, A. G. (2000). Molecular characterization of the ligand-receptor interaction of the neuropeptide Y family. J. Pept. Sci. 6, 97-122.

Cabrele, C., Langer, M., Bader, R., Wieland, H. A., Doods, H. N., Zerbe, O., etal. (2000). The first selective agonist for the neuropeptide YY5 receptor increases food intake in rats. J. Biol. Chem. 275, 36043 36048 .

Cabrele, C., Wieland, H. A., Koglin, N., Stidsen, C., and Beck-Sickinger, A. G. (2002). Ala31-Aib32: identification of the key motif for high affinity and selectivity of neuropeptide $\mathrm{Y}$ at the Y5-receptor. Biochemistry 41, 8043-8049.

Castan, I., Valet, P., Larrouy, D., Voisin, T., Remaury, A., Daviaud, D., et al. (1993). Distribution of PYY receptors in human fat cells: an antilipolytic system alongside the alpha 2adrenergic system. Am. J. Physiol. 265, E74-E80
Cherezov, V., Rosenbaum, D. M., Hanson, M. A., Rasmussen, S. G., Thian, F. S., Kobilka, T. S., et al. (2007). Highresolution crystal structure of an engineered human beta2-adrenergic $\mathrm{G}$ protein-coupled receptor. Science 318, 1258-1265.

Criscione, L., Rigollier, P., BatzlHartmann, C., Rueger, H., StrickerKrongrad, A., Wyss, P., et al. (1998). Food intake in free-feeding and energy-deprived lean rats is mediated by the neuropeptide Y5 receptor. J. Clin. Invest. 102, 2136-2145.

Doods, H., Gaida, W., Wieland, H. A., Dollinger, H., Schnorrenberg, G., Esser, F., et al. (1999). BIIE0246: selective and high affinity neuropeptide Y Y(2) receptor antagonist. Eur. J. Pharmacol. 384, R3-R5.

Eckard, C. P., Cabrele, C., Wieland, H. A., and Beck-Sickinger, A. G. (2001). Characterisation of neuropeptide $\mathrm{Y}$ receptor subtypes by synthetic NPY analogues and by anti-receptor antibodies. Molecules 6, 448-467.

Edelsbrunner, M. E., Painsipp, E., Herzog, H., and Holzer, P. (2009) Evidence from knockout mice for distinct implications of neuropeptide- $Y$ $\mathrm{Y} 2$ and $\mathrm{Y} 4$ receptors in the circadian control of locomotion, exploration, water and food intake. Neuropeptides 43, 491-497.

Erondu, N., Wadden, T., Gantz, I., Musser, B., Nguyen, A. M., Bays, H., et al. (2007). Effect of NPY5R antagonist MK-0557 on weight regain after very-low-calorie diet-induced weight loss. Obesity (Silver Spring) 15, 895905

Fallmar, H., Akerberg, H., GutierrezDe-Teran, H., Lundell, I., Mohell, N., and Larhammar, D. (2011). Identification of positions in the human neuropeptide Y/peptide YY receptor Y2 that contribute to pharmacological differences between receptor subtypes. Neuropeptides 45, 293-300.

Ferrier, L., Segain, J. P., Bonnet, C. Cherbut, C., Lehur, P. A., Jarry, A., et al. (2002). Functional mapping of NPY/PYY receptors in rat and human gastro-intestinal tract. Peptides 23, 1765-1771.

Flood, J. F., and Morley, J. E. (1989). Dissociation of the effects of neuropeptide $\mathrm{Y}$ on feeding and memory: evidence for pre- and postsynaptic mediation. Peptides 10, 963-966.

Fournier, A., Gagnon, D., Quirion, R., Cadieux, A., Dumont, Y., Pheng, L. H., et al. (1994). Conformational and biological studies of neuropeptide-Y analogs containing structural alterations. Mol. Pharmacol. 45, 93-101.

Fuhlendorff, J., Gether, U., Aakerlund, L., Langeland-Johansen, N.,
Thogersen, H., Melberg, S. G., et al. (1990). [Leu31, Pro34]neuropeptide Y: a specific Y1 receptor agonist. Proc. Natl. Acad. Sci. U.S.A. 87, 182-186.

Gehlert, D. R. (1998). Multiple receptors for the pancreatic polypeptide (PP-fold) family: physiological implications. Proc. Soc. Exp. Biol. Med. 218, 7-22.

Gerald, C., Walker, M. W., Criscione, L., Gustafson, E. L., Batzl-Hartmann, C., Smith, K. E., et al. (1996). A receptor subtype involved in neuropeptideY-induced food intake. Nature 382, 168-171.

Golombek, D. A., Biello, S. M., Rendon, R. A., and Harrington, M. E. (1996). Neuropeptide Y phase shifts the circadian clock in vitro via a Y2 receptor. Neuroreport 7, 1315-1319.

Gribkoff, V. K., Pieschl, R. L., Wisialowski, T. A., Van Den Pol, A. N., and Yocca, F. D. (1998). Phase shifting of circadian rhythms and depression of neuronal activity in the rat suprachiasmatic nucleus by neuropeptide Y: mediation by different receptor subtypes. J. Neurosci. 18, 3014-3022.

Haack, M., Enck, S., Seger, H., Geyer, A., and Beck-Sickinger, A. G. (2008). Pyridone dipeptide backbone scan to elucidate structural properties of a flexible peptide segment. J. Am. Chem. Soc. 130, 8326-8336.

Hankir, M. K., Parkinson, J. R., Minnion, J. S., Addison, M. L., Bloom, S. R., and Bell, J. D. (2011). Peptide YY 3-36 and pancreatic polypeptide differentially regulate hypothalamic neuronal activity in mice in vivo as measured by manganese-enhanced magnetic resonance imaging. J. Neuroendocrinol. 23, 371-380.

Hausman, G. J., Barb, C. R., and Dean, R. G. (2008). Patterns of gene expression in pig adipose tissue: insulin-like growth factor system proteins, neuropeptide Y (NPY), NPY receptors, neurotrophic factors and other secreted factors. Domest. Anim. Endocrinol. 35, 24-34.

Heilig, M. (2004). The NPY system in stress, anxiety and depression. $\mathrm{Neu}$ ropeptides 38, 213-224.

Hipskind, P. A., Lobb, K. L., Nixon, J. A., Britton, T. C., Bruns, R. F., Catlow, J., et al. (1997). Potent and selective 1,2,3-trisubstituted indole NPY Y-1 antagonists. J. Med. Chem. 40, 3712-3714.

Hoffmann, S., Rist, B., Videnov, G., Jung, G., and Beck-Sickinger, A. G. (1996). Structure-affinity studies of C-terminally modified analogs of neuropeptide $\mathrm{Y}$ led to a novel class of peptidic Y1 receptor antagonist. Regul. Pept. 65, 61-70. 
Holland-Nell, K., and Meldal, M. (2011). Maintaining biological activity by using triazoles as disulfide bond mimetics. Angew. Chem. Int. Ed. Engl. 50, 5204-5206.

Holliday, N. D., Michel, M. C., and Cox, H. M. (2004). "NPY receptor subtypes and their signal transduction" in Neuropeptide $Y$ and Related Peptides, ed. M. C. Michel (Berlin: Springer), 45-73.

Jablonowski, J. A., Chai, W., Li, X., Rudolph, D. A., Murray, W. V., Youngman, M. A., et al. (2004). Novel nonpeptidic neuropeptide Y Y2 receptor antagonists. Bioorg. Med. Chem. Lett. 14, 1239-1242.

Jain, M. R., Pu, S., Kalra, P. S., and Kalra, S. P. (1999). Evidence that stimulation of two modalities of pituitary luteinizing hormone release in ovarian steroid-primed ovariectomized rats may involve neuropeptide Y Y1 and Y4 receptors. Endocrinology 140, 5171-5177.

Kakui, N., Tanaka, J., Tabata, Y., Asai, K., Masuda, N., Miyara, T., et al. (2006). Pharmacological characterization and feeding-suppressive property of FMS586 [3-(5,6,7,8tetrahydro-9-isopropyl-carbazol-3yl)-1-methyl-1-(2-pyridin-4-yl-ethy 1)-urea hydrochloride], a novel, selective, and orally active antagonist for neuropeptide Y Y5 receptor. $J$. Pharmacol. Exp. Ther. 317, 562-570.

Kanatani, A., Ishihara, A., Iwaasa, H., Nakamura, K., Okamoto, O., Hidaka, M., et al. (2000a). L-152,804: orally active and selective neuropeptide $\mathrm{Y}$ Y5 receptor antagonist. Biochem. Biophys. Res. Commun. 272, 169-173.

Kanatani, A., Mashiko, S., Murai, N., Sugimoto, N., Ito, J., Fukuroda, T., et al. (2000b). Role of the Y1 receptor in the regulation of neuropeptide Y-mediated feeding: comparison of wild-type, Y1 receptor-deficient, and Y5 receptor-deficient mice. Endocrinology 141, 1011-1016.

Kannoa, T., Kanatani, A., Keen, S. L., Arai-Otsuki, S., Haga, Y., Iwama, T., et al. (2001). Different binding sites for the neuropeptide $Y Y 1$ antagonists 1229U91 and J-104870 on human Y1 receptors. Peptides 22, 405-413.

Keire, D. A., Kobayashi, M., Solomon, T. E., and Reeve, J. R. Jr. (2000a). Solution structure of monomeric peptide YY supports the functional significance of the PP-fold. Biochemistry 39, 9935-9942.

Keire, D. A., Mannon, P., Kobayashi, M., Walsh, J. H., Solomon, T. E., and Reeve, J. R. Jr. (2000b). Primary structures of PYY, [Pro(34)]PYY, and PYY-(3-36) confer different conformations and receptor selectivity. Am.
J. Physiol. Gastrointest. Liver Physiol. 279, G126-G131.

Kimmel, J. R., Hayden, L. J., and Pollock, H. G. (1975). Isolation and characterization of a new pancreatic polypeptide hormone. J. Biol. Chem. 250, 9369-9376.

Kirby, D. A., Boublik, J. H., and Rivier, J. E. (1993a). Neuropeptide Y: $\mathrm{Y} 1$ and Y2 affinities of the complete series of analogues with single Dresidue substitutions. J. Med. Chem. 36, 3802-3808.

Kirby, D. A., Koerber, S. C., Craig, A. G., Feinstein, R. D., Delmas, L., Brown, M. R., et al. (1993b). Defining structural requirements for neuropeptide $\mathrm{Y}$ receptors using truncated and conformationally restricted analogues. $J$. Med. Chem. 36, 385-393.

Koglin, N., Zorn, C., Beumer, R. Cabrele, C., Bubert, C., Sewald, N., etal. (2003). Analogues of neuropeptide $\mathrm{Y}$ containing betaaminocyclopropane carboxylic acids are the shortest linear peptides that are selective for the $\mathrm{Y} 1$ receptor. Angew. Chem. Int. Ed. Engl. 42, 202-205.

Larhammar, D. (1996). Structural diversity of receptors for neuropeptide $\mathrm{Y}$, peptide YY and pancreatic polypeptide. Regul. Pept. 65, 165-174.

Larhammar, D., and Salaneck, E. (2004). Molecular evolution of NPY receptor subtypes. Neuropeptides 38, 141-151.

Larhammar, D., Wraith, A., Berglund, M. M., Holmberg, S. K., and Lundell, I. (2001). Origins of the many NPY-family receptors in mammals. Peptides 22, 295-307.

Lee, C. C., and Miller, R. J. (1998), Is there really an NPY Y3 receptor? Regul. Pept. 75-76, 71-78.

Lerch, M., Mayrhofer, M., and Zerbe, O. (2004). Structural similarities of micelle-bound peptide YY (PYY) and neuropeptide Y (NPY) are related to their affinity profiles at the $\mathrm{Y}$ receptors. J. Mol. Biol. 339, 1153-1168.

Lindner, D., Stichel, J., and BeckSickinger, A. G. (2008a). Molecular recognition of the NPY hormone family by their receptors. Nutrition 24, 907-917.

Lindner, D., Van Dieck, J., Merten, N., Morl, K., Gunther, R., Hofmann, H. J., etal. (2008b). GPC receptors and not ligands decide the binding mode in neuropeptide $Y$ multireceptor/multiligand system. Biochemistry 47, 5905-5914.

Lindner, D., Walther, C., Tennemann, A., and Beck-Sickinger, A. G. (2009). Functional role of the extracellular $\mathrm{N}$-terminal domain of neuropeptide $\mathrm{Y}$ subfamily receptors in membrane integration and agonist-stimulated internalization. Cell. Signal. 21, 61-68.

Lundberg, J. M., Tatemoto, K., Terenius, L., Hellstrom, P. M., Mutt, V., Hokfelt, T., et al. (1982). Localization of peptide YY (PYY) in gastrointestinal endocrine cells and effects on intestinal blood flow and motility. Proc. Natl. Acad. Sci. U.S.A. 79, 4471-4475.

Lundell, I., Blomqvist, A. G., Berglund, M. M., Schober, D. A., Johnson, D., Statnick, M. A., et al. (1995). Cloning of a human receptor of the NPY receptor family with high affinity for pancreatic polypeptide and peptide YY. J. Biol. Chem. 270, 29123-29128.

Lunniss, G. E., Barnes, A. A., Barton, N., Biagetti, M., Bianchi, F., Blowers, S. M., et al. (2009). The identification and optimisation of novel and selective diamide neuropeptide Y Y2 receptor antagonists. Bioorg. Med. Chem. Lett. 19, 4022-4025.

Lunniss, G. E., Barnes, A. A., Barton, N. Biagetti, M., Bianchi, F., Blowers, S. M., et al. (2010). The identification of a series of novel, soluble non-peptidic neuropeptide Y Y2 receptor antagonists. Bioorg. Med. Chem. Lett. 20, 7341-7344.

Matsumoto, M., Nomura, T., Momose, K., Ikeda, Y., Kondou, Y., Akiho, H., et al. (1996a). Inactivation of a novel neuropeptide Y/peptide YY receptor gene in primate species. J. Biol. Chem 271, 27217-27220.

Matsumoto, S., Basil, J., Jetton, A. E., Lehman, M. N., and Bittman, E. L. (1996b). Regulation of the phase and period of circadian rhythms restored by suprachiasmatic transplants. J. Biol. Rhythms 11, 145-162.

Merten, N., Lindner, D., Rabe, N. Rompler, H., Morl, K., Schoneberg, T., et al. (2007). Receptor subtypespecific docking of Asp6.59 with $\mathrm{C}$-terminal arginine residues in $\mathrm{Y}$ receptor ligands. J. Biol. Chem. 282, 7543-7551.

Michel, M. C., Beck-Sickinger, A., Cox, H., Doods, H. N., Herzog, H., Larhammar, D., et al. (1998) XVI. International Union of Pharmacology recommendations for the nomenclature of neuropeptide $\mathrm{Y}$, peptide YY, and pancreatic polypeptide receptors. Pharmacol. Rev. 50, 143-150.

Misra, S., Murthy, K. S., Zhou, H., and Grider, J. R. (2004). Coexpression of $\mathrm{Y} 1, \mathrm{Y} 2$, and Y4 receptors in smooth muscle coupled to distinct signaling pathways. J. Pharmacol. Exp. Ther. 311, 1154-1162.

Mittapalli, G. K., Vellucci, D., Yang, J., Toussaint, M., Brothers, S. P., Wahlestedt, C, et al. (2012). Synthesis and SAR of selective small molecule neuropeptide $\mathrm{Y} Y 2$ receptor antagonists. Bioorg. Med. Chem. Lett. 22, 3916-3920.

Moriya, R., Fujikawa, T., Ito, J., Shirakura, T., Hirose, H., Suzuki, J., et al. (2010). Pancreatic polypeptide enhances colonic muscle contraction and fecal output through neuropeptide Y Y4 receptor in mice. Eur. J. Pharmacol. 627, 258-264.

Mullins, D., Adham, N., Hesk, D., Wu, Y., Kelly, J., Huang, Y., et al. (2008). Identification and characterization of pseudoirreversible nonpeptide antagonists of the neuropeptide Y Y5 receptor and development of a novel Y5-selective radioligand. Eur. J. Pharmacol. 601, 1-7.

Mullins, D., Kirby, D., Hwa, J., Guzzi, M., Rivier, J., and Parker, E. (2001). Identification of potent and selective neuropeptide Y Y(1) receptor agonists with orexigenic activity in vivo. Mol. Pharmacol. 60, 534-540.

Neumoin, A., Mares, J., Lerch-Bader, M., Bader, R., and Zerbe, O. (2007). Probing the formation of stable tertiary structure in a model miniprotein at atomic resolution: determinants of stability of a helical hairpin. J. Am. Chem. Soc. 129, 8811-8817.

Palczewski, K., Kumasaka, T., Hori, T., Behnke, C. A., Motoshima, H., Fox, B. A., et al. (2000). Crystal structure of rhodopsin: a $G$ protein-coupled receptor. Science 289, 739-745.

Parker, E. M., Babij, C. K., Balasubramaniam, A., Burrier, R. E., Guzzi, M., Hamud, F., et al. (1998). GR231118 (1229U91) and other analogues of the $\mathrm{C}$-terminus of neuropeptide $\mathrm{Y}$ are potent neuropeptide Y Y1 receptor antagonists and neuropeptide Y Y4 receptor agonists. Eur. J. Pharmacol. 349, 97-105.

Parker, E. M., Balasubramaniam, A., Guzzi, M., Mullins, D. E., Salisbury, B. G., Sheriff, S., etal. (2000). [D$\operatorname{Trp}(34)]$ neuropeptide $\mathrm{Y}$ is a potent and selective neuropeptide $\mathrm{Y} Y(5)$ receptor agonist with dramatic effects on food intake. Peptides 21, 393-399.

Parker, M. S., Sah, R., Balasubramaniam, A., Sallee, F. R., Zerbe, O., and Parker, S. L. (2011). Non-specific binding and general cross-reactivity of $\mathrm{Y}$ receptor agonists are correlated and should importantly depend on their acidic sectors. Peptides 32, 258265.

Pedersen, S. L., Holst, B., Vrang, N., and Jensen, K. J. (2009). Modifying the conserved C-terminal tyrosine of the peptide hormone PYY3-36 to improve Y2 receptor selectivity. $J$. Pept. Sci. 15, 753-759.

Pittner, R. A., Moore, C. X., Bhavsar, S. P., Gedulin, B. R., Smith, P. A., 
Jodka, C. M., et al. (2004). Effects of PYY [3-36] in rodent models of diabetes and obesity. Int. J. Obes. Relat. Metab. Disord. 28, 963-971.

Potter, E. K., Mitchell, L., Mccloskey, M. J., Tseng, A., Goodman, A. E., Shine, J., et al. (1989). Pre- and postjunctional actions of neuropeptide $\mathrm{Y}$ and related peptides. Regul. Pept. 25, 167-177.

Raposinho, P. D., Pierroz, D. D., Broqua, P., White, R. B., Pedrazzini, T., and Aubert, M. L. (2001). Chronic administration of neuropeptide $\mathrm{Y}$ into the lateral ventricle of C57BL/6 J male mice produces an obesity syndrome including hyperphagia, hyperleptinemia, insulin resistance, and hypogonadism. Mol. Cell. Endocrinol. 185, 195-204.

Rodriguez, M., Audinot, V., Dromaint, S., Macia, C., Lamamy, V., Beauverger, P., et al. (2003). Molecular identification of the long isoform of the human neuropeptide Y Y5 receptor and pharmacological comparison with the short Y5 receptor isoform. Biochem. J. 369, 667-673.

Rudolf, K., Eberlein, W., Engel, W., Wieland, H. A., Willim, K. D., Entzeroth, M., et al. (1994). The first highly potent and selective nonpeptide neuropeptide Y Y1 receptor antagonist: BIBP3226. Eur. J. Pharmacol. 271, R11-R13.

Rueeger, H., Rigollier, P., Yamaguchi, Y., Schmidlin, T., Schilling, W., Criscione, L., et al. (2000). Design, synthesis and SAR of a series of 2-substituted 4-aminoquinazoline neuropeptide YY5 receptor antagonists. Bioorg. Med. Chem. Lett. 10, 1175-1179.

Sainsbury, A., Shi, Y. C., Zhang, L., Aljanova, A., Lin, Z., Nguyen, A. D., etal. (2010). Y4 receptors and pancreatic polypeptide regulate food intake via hypothalamic orexin and brain-derived neurotropic factor dependent pathways. Neuropeptides 44, 261-268.

Salaneck, E., Holmberg, S. K., Berglund, M. M., Boswell, T., and Larhammar, D. (2000). Chicken neuropeptide Y receptor Y2: structural and pharmacological differences to mammalian Y2(1). FEBS Lett. 484, 229-234.

Saldanha, S. A., Brothers, S. P., Spicer, T., Cameron, M., Mercer, B. A., Chase, P., et al. (2009). "Probe report for NPY-Y2 receptor antagonists," in Probe Reports from the NIH Molecular Libraries Program [Internet] (Bethesda, MD: National Center for Biotechnology Information). Available at: http://www.ncbi.nlm.nih.gov/books/
NBK47354/ [updated August 6, 2010].

Sautel, M., Martinez, R., Munoz, M. Peitsch, M. C., Beck-Sickinger, A. G., and Walker, P. (1995). Role of a hydrophobic pocket of the human Y1 neuropeptide Y receptor in ligand binding. Mol. Cell. Endocrinol. 112, 215-222.

Sautel, M., Rudolf, K., Wittneben, H., Herzog, H., Martinez, R., Munoz, M., et al. (1996). Neuropeptide Y and the nonpeptide antagonist BIBP 3226 share an overlapping binding site at the human $\mathrm{Y} 1$ receptor. Mol. Pharmacol. 50, 285-292.

Schloegl, H., Percik, R., Horstmann, A., Villringer, A., and Stumvoll, M. (2011). Peptide hormones regulating appetite - focus on neuroimaging studies in humans. Diabetes Metab. Res. Rev. 27, 104-112.

Schober, D. A., Van Abbema, A. M., Smiley, D. L., Bruns, R. F., and Gehlert, D. R. (1998). The neuropeptide Y Y1 antagonist, 1229U91, a potent agonist for the human pancreatic polypeptide-preferring (NPY Y4) receptor. Peptides 19, 537-542.

Schwartz, T. W. (2006). Y2/Y4 Selective Receptor Agonists for Therapeutic Intervention. Patent GB20060018812.2.

Shoblock, J. R., Welty, N., Nepomuceno, D., Lord, B., Aluisio, L., Fraser, I., etal. (2010). In vitro and in vivo characterization of JNJ-31020028 (N-(4-\{4-[2-(diethylamino)-2-oxo1-phenylethyl]piperazin-1-yl\}-3fluorophenyl)-2- pyridin-3-ylbenzamide), a selective brain penetrant small molecule antagonist of the neuropeptide Y Y(2) receptor. Psychopharmacology (Berl) 208, 265-277.

Sjodin, P., Holmberg, S. K., Akerberg, H., Berglund, M. M., Mohell, N., and Larhammar, D. (2006). Reevaluation of receptor-ligand interactions of the human neuropeptide Y receptor Y1: a site-directed mutagenesis study. Biochem. J. 393, 161-169.

Soll, R. M., Dinger, M. C., Lundell, I., Larhammer, D., and Beck-Sickinger, A. G. (2001). Novel analogues of neuropeptide $\mathrm{Y}$ with a preference for the Y1-receptor. Eur. J. Biochem. 268, 2828-2837.

Sousa, D. M., Baldock, P. A., Enriquez, R. F., Zhang, L., Sainsbury, A., Lamghari, M., et al. (2012). Neuropeptide Y Y1 receptor antagonism increases bone mass in mice. Bone 51, 8-16.

Stanley, B. G., Kyrkouli, S. E., Lampert, S., and Leibowitz, S. F. (1986). Neuropeptide Y chronically injected into the hypothalamus: a powerful neurochemical inducer of hyperphagia and obesity. Peptides 7, 1189-1192.

Starback, P., Wraith, A., Eriksson, H., and Larhammar, D. (2000). Neuropeptide $\mathrm{Y}$ receptor gene $\mathrm{y} 6$ : multiple deaths or resurrections? Biochem. Biophys. Res. Commun. 277, 264-269. Suzuki, K., Simpson, K. A., Minnion, J. S., Shillito, J. C., and Bloom, S. R. (2010). The role of gut hormones and the hypothalamus in appetite regulation. Endocr. J. 57, 359-372.

Swanson, D. M., Wong, V. D. Jablonowski, J. A., Shah, C., Rudolph, D. A., Dvorak, C. A., et al. (2011). The discovery and synthesis of JN] 31020028, a small molecule antagonist of the Neuropeptide Y Y(2) receptor. Bioorg. Med. Chem. Lett. 21, 5552-5556.

Tatemoto, K. (1982). Neuropeptide Y: complete amino acid sequence of the brain peptide. Proc. Natl. Acad. Sci. U.S.A. 79, 5485-5489.

Tatemoto, K., and Mutt, V. (1980). Isolation of two novel candidate hormones using a chemical method for finding naturally occurring polypeptides. Nature 285, 417-418.

Thiele, T. E., Marsh, D. J., Ste Marie, L., Bernstein, I. L., and Palmiter, R. D. (1998). Ethanol consumption and resistance are inversely related to neuropeptide Y levels. Nature 396, 366-369.

Verdine, G. L., and Walensky, L. D. (2007). The challenge of drugging undruggable targets in cancer: lessons learned from targeting BCL2 family members. Clin. Cancer Res. 13, 7264-7270.

Wahlestedt, C., Yanaihara, N., and Hakanson, R. (1986). Evidence for different pre-and post-junctional receptors for neuropeptide $\mathrm{Y}$ and related peptides. Regul. Pept. 13, 307-318.

Walther, C., Morl, K., and BeckSickinger, A. G. (2011). Neuropeptide Y receptors: ligand binding and trafficking suggest novel approaches in drug development. J. Pept. Sci. 17, 233-246.

Wharton, J., Gordon, L., Byrne, J., Herzog, H., Selbie, L. A., Moore, K., et al. (1993). Expression of the human neuropeptide tyrosine Y1 receptor. Proc. Natl. Acad. Sci. U.S.A. 90, 687-691.

Widdowson, P. S. (1993). Quantitative receptor autoradiography demonstrates a differential distribution of neuropeptide-Y Y1 and Y2 receptor subtypes in human and rat brain. Brain Res. 631, 27-38.

Widdowson, P. S., Buckingham, R., and Williams, G. (1997). Distribution of [Leu31,Pro34]NPY-sensitive, BIBP3226-insensitive [125I]PYY(336) binding sites in rat brain: possible relationship to Y5 NPY receptors. Brain Res. 778, 242-250.

Wieland, H. A., Engel, W., Eberlein, W., Rudolf, K., and Doods, H. N. (1998). Subtype selectivity of the novel nonpeptide neuropeptide Y Y1 receptor antagonist BIBO 3304 and its effect on feeding in rodents. $\mathrm{Br}$. $\mathrm{J}$. Pharmacol. 125, 549-555.

Zhang, L., Bijker, M. S., and Herzog, H. (2011). The neuropeptide Y system: pathophysiological and therapeutic implications in obesity and cancer. Pharmacol. Ther. 131,91-113.

Ziemek, R., Schneider, E., Kraus, A., Cabrele, C., Beck-Sickinger, A. G., Bernhardt, G., et al. (2007). Determination of affinity and activity of ligands at the human neuropeptide Y Y4 receptor by flow cytometry and aequorin luminescence. J. Recept. Signal Transduct. Res. 27, 217-233.

Zukowska-Grojec, Z., KarwatowskaProkopczuk, E., Rose, W., Rone, J., Movafagh, S., Ji, H., et al. (1998). Neuropeptide Y: a novel angiogenic factor from the sympathetic nerves and endothelium. Circ. Res. 83, 187195.

Zwanziger, D., Bohme, I., Lindner, D., and Beck-Sickinger, A. G. (2009). First selective agonist of the neuropeptide Y1-receptor with reduced size. J. Pept. Sci. 15, 856-866.

Conflict of Interest Statement: The authors declare that the research was conducted in the absence of any commercial or financial relationships that could be construed as a potential conflict of interest.

Received: 29 August 2012; paper pending published: 02 October 2012; accepted: 09 January 2013; published online: 04 February 2013.

Citation: Pedragosa-Badia X, Stichel J and Beck-Sickinger AG (2013) Neuropeptide Y receptors: how to get subtype selectivity. Front. Endocrin. 4:5. doi: 10.3389/ fendo.2013.00005

This article was submitted to Frontiers in Neuroendocrine Science, a specialty of Frontiers in Endocrinology.

Copyright (c) 2013 Pedragosa-Badia, Stichel and Beck-Sickinger. This is an open-access article distributed under the terms of the Creative Commons Attribution License, which permits use, distribution and reproduction in other forums, provided the original authors and source are credited and subject to any copyright notices concerning any third-party graphics etc. 